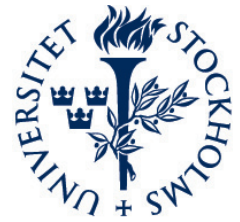 \\ Licentiate thesis \\ Stockholm \\ University \\ Geology
}

\section{Chemical controls on ikaite formation}

Elin Tollefsen

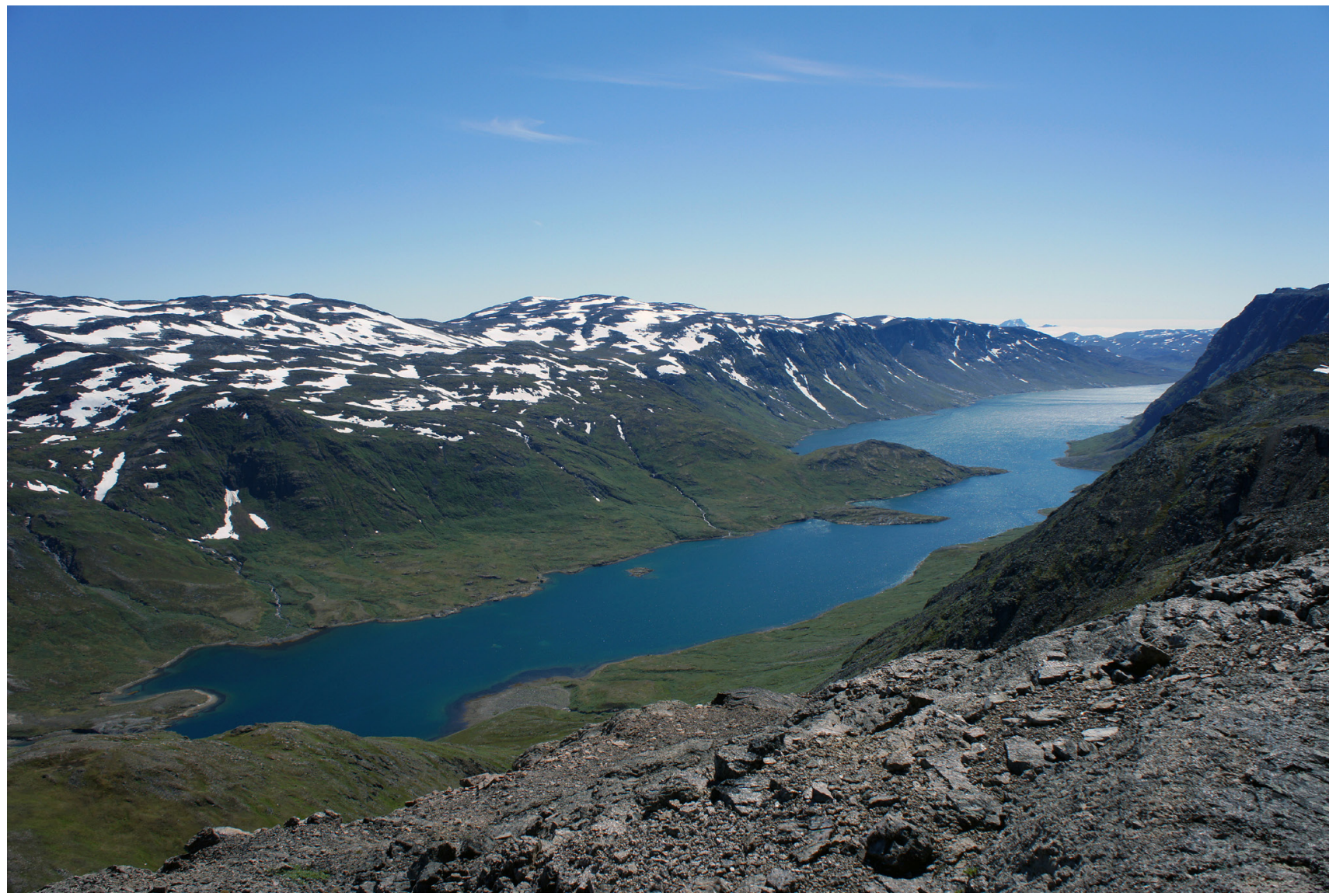

Stockholm 2017

Department of Geological Sciences

Stockholm University

SE-106 91 Stockholm 



\begin{abstract}
The metastable mineral ikaite $\left(\mathrm{CaCO}_{3} \cdot 6 \mathrm{H}_{2} \mathrm{O}\right)$ was considered rare when it was first discovered as tufa columns forming above carbonated submarine springs in Ikka Fjord, southwest Greenland. Ikaite has since then been found in marine sediments and in sea ice. It is also the precursor of a common pseudomorph glendonite. Why this mineral forms instead of the stable phase calcite is unclear. However, it has been suggested that cold temperature $\left(<6^{\circ} \mathrm{C}\right)$, the presence of $\mathrm{Mg}$ and $\mathrm{SO}_{4}$ in the seawater and high $\mathrm{pH}$ in the spring water favoured ikaite formation in Ikka Fjord. This thesis presents an experimental study in which the chemical controls on ikaite precipitation are tested by simulating Ikka Fjord conditions. Natural seawater, synthetic seawater or synthetic seawater with $\mathrm{SO}_{4}$ or $\mathrm{Mg}$ removed was mixed at a constant rate with a $0.1 \mathrm{M} \mathrm{Na}_{2} \mathrm{CO}_{3}+0.1 \mathrm{M} \mathrm{NaHCO}_{3}$ solution with different ratios of $\mathrm{Na}_{2} \mathrm{CO}_{3} / \mathrm{NaHCO}_{3}$, representing the carbonated spring water. The results showed that ikaite precipitated in experiments with natural seawater, synthetic seawater or synthetic seawater with $\mathrm{SO}_{4}$ removed. However, in experiments with $\mathrm{Mg}$ removed from the synthetic seawater, calcite precipitated instead of ikaite. Ikaite did not precipitate at $\mathrm{pH}$ $<9.3$, instead calcite or aragonite precipitated. From the results of the 47 experiments a kinetic stability diagram was constructed for the transition from metastable ikaite to calcite as a function of $\mathrm{Mg}$ concentration and $\mathrm{pH}$ at $5^{\circ} \mathrm{C}$. One explanation for these results is the inhibition of calcite by $\mathrm{Mg}$.
\end{abstract}




\section{Sammanfattning}

Det instabila mineralet ikait $\left(\mathrm{CaCO}_{3} \cdot 6 \mathrm{H}_{2} \mathrm{O}\right)$ ansågs sällsynt när det först upptäcktes som tuffa kolumner stående ovan karbonat rika undervattens källor på botten av Ikka fjorden på sydvästra Grönland. Sedan dess har mineralet hittats i marina sediment och i havs is, mineralet är också föregångare till en vanlig pseudomorf, glendonit. Varför ikait bildas istället för det mer stabila kalcit är oklart. Det har föreslagits att låg temperatur $\left(<6^{\circ} \mathrm{C}\right)$, $\mathrm{Mg}$ och $\mathrm{SO}_{4} \mathrm{i}$ havsvattnet och högt $\mathrm{pH}$ i källvattnet favoriserar ikait bildning i Ikka fjorden. Den här avhandlingen presenterar en experimentell studie där kemisk kontroll över ikait utfällning undersöks genom att simulera Ikka fjord förhållanden. Naturligt havsvatten, syntetiskt havsvatten eller syntetsikt havsvatten utan $\mathrm{SO}_{4}$ eller utan $\mathrm{Mg}$ blandades med ett jämt flöde med en lösning av $0.1 \mathrm{M} \mathrm{Na}_{2} \mathrm{CO}_{3}+0.1 \mathrm{M} \mathrm{NaHCO}_{3}$ i olika proportioner, vilket representerar det karbonat rika källvattnet. Resultaten visar att ikait utfälls i experiment med naturligt havsvatten, syntetiskt havsvatten eller syntetiskt havsvatten utan $\mathrm{SO}_{4}$, däremot i experiment med syntetiskt havsvatten utan Mg fälldes kalcit ut i stället för ikait. Ikait fälldes inte ut vid $\mathrm{pH}<9.3$ istället bildades då kalcit eller aragonit. Från resultaten utav de 47 experimenten konstruerades ett kinetiskt stabilitets diagram för övergången från instabila ikaite till kalcite som en funktion av $\mathrm{Mg}$ konsentration och $\mathrm{pH}$ vid $5^{\circ} \mathrm{C}$. En förklaring till våra resultat kan var att Mg inhiberar kalcit. 


\section{Table of Contents}

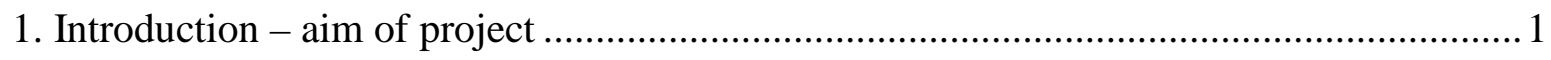

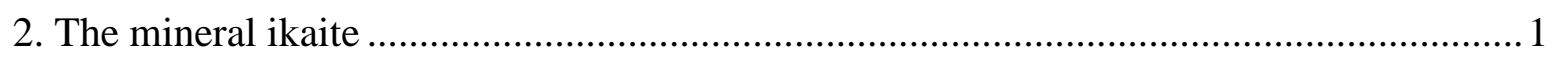

2.1. From calcium carbonate hexahydrate to ikaite ......................................................... 1

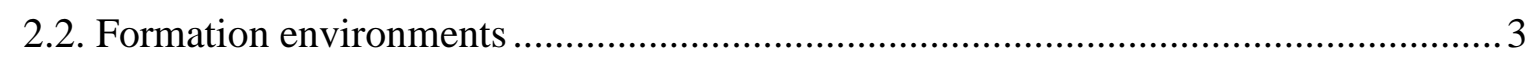

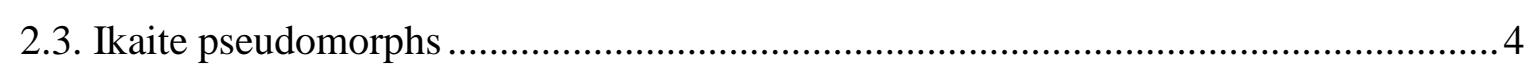

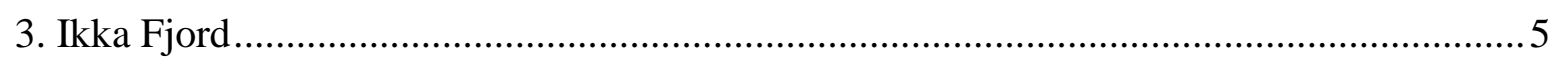

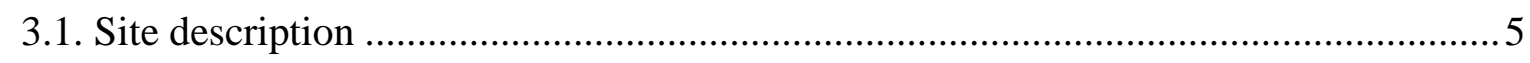

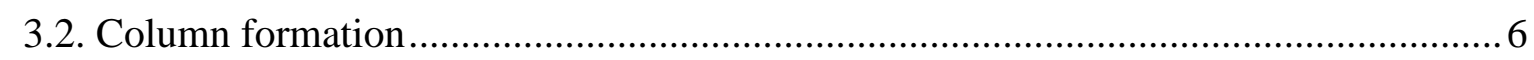

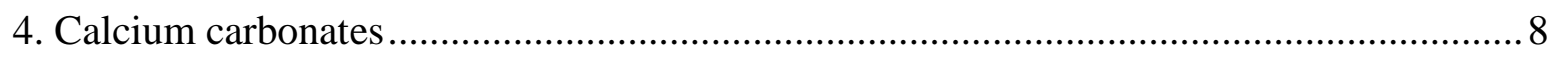

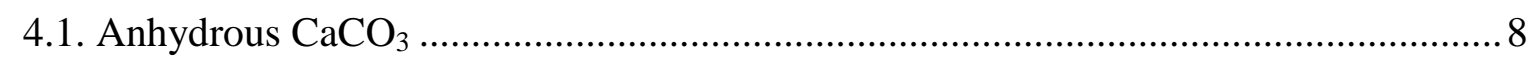

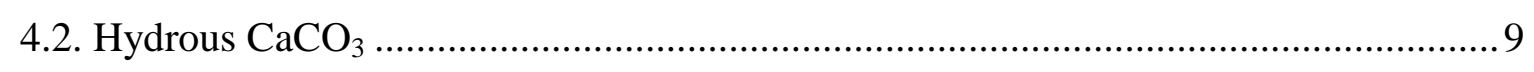

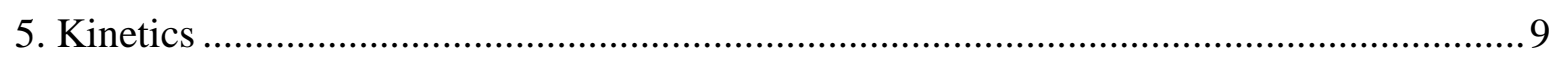

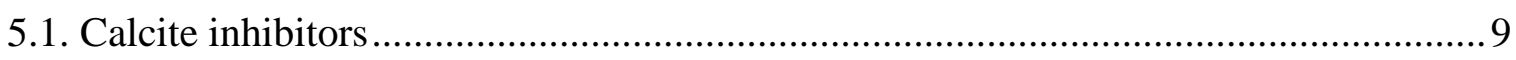

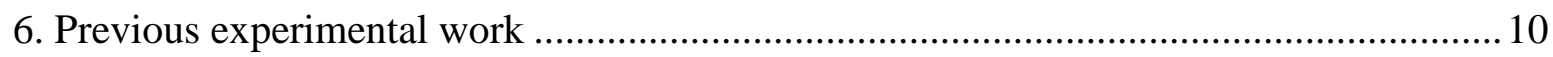

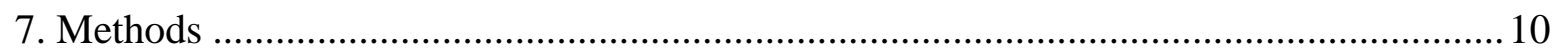

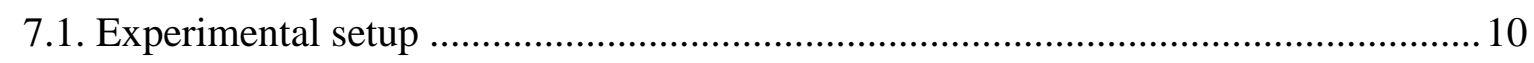

7.1.1. Geochemical modelling ..................................................................................... 11

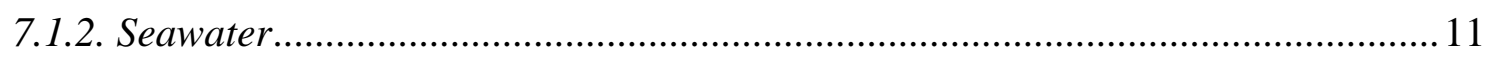

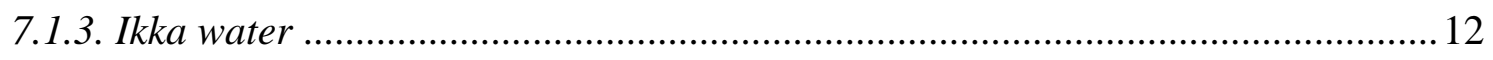

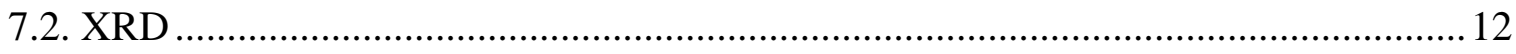

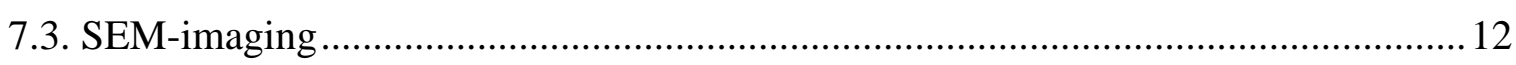

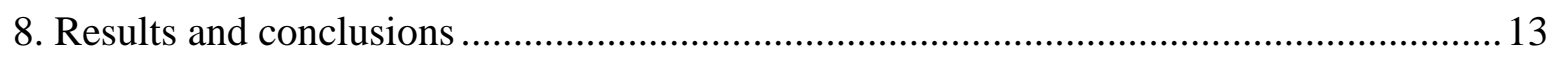

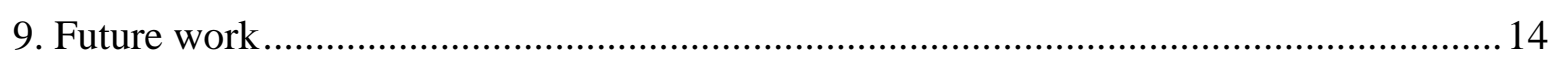

9.1. Low temperature alteration in Grønnedal-Íka igneous complex ................................ 14

9.2. Ikaite pseudomorphs in Neoproterozoic dolostones on Islay, Scotland ..................... 14

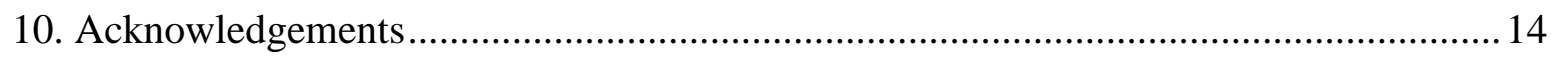

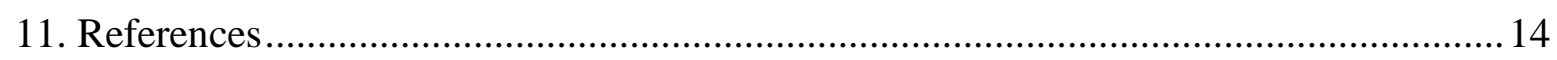

MANUSCRIPT

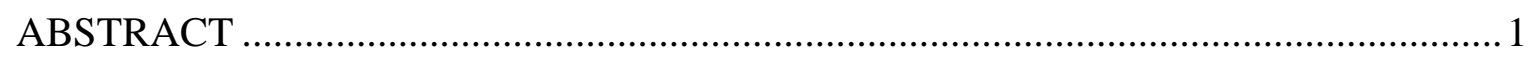

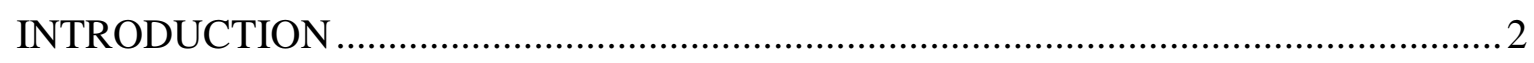




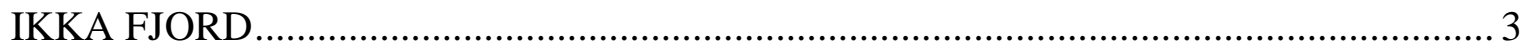

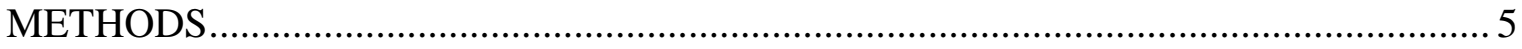

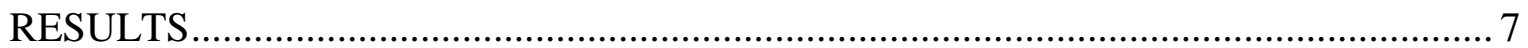

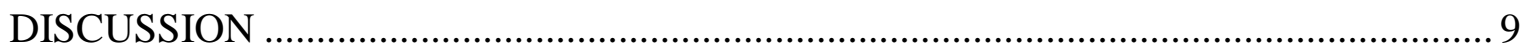

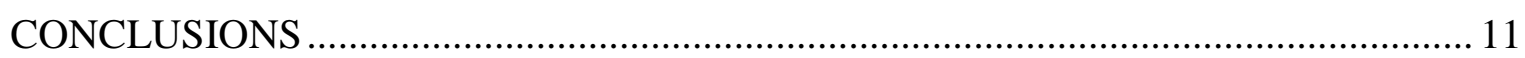

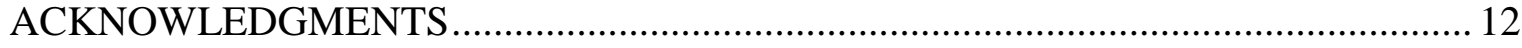

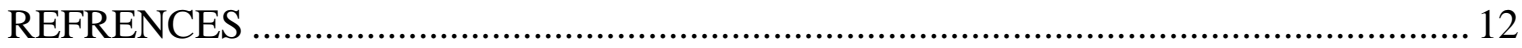

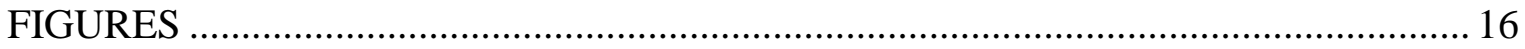

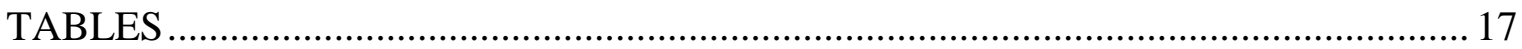

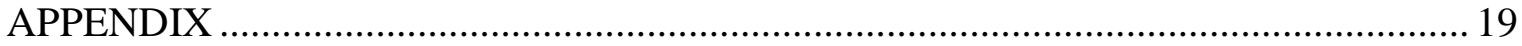




\section{Introduction - aim of project}

This thesis presents an experimental study with the aim of identifying the chemical factors which control the formation of the mineral ikaite $\left(\mathrm{CaCO}_{3} \cdot 6 \mathrm{H}_{2} \mathrm{O}\right)$. This mineral, which is metastable at surface conditions, nevertheless precipitates rapidly in Ikka Fjord, southwest Greenland. The study is part of a PhD-project which focuses on the environment and process of formation of this mineral both in Greenland and in Neoproterozoic metasediments on Islay, western Scotland.

\section{The mineral ikaite}

\subsection{From calcium carbonate hexahydrate to ikaite}

Long before ikaite was found in nature, it was discovered as calcium carbonate hexahydrate in laboratory experiments. It was first mentioned in the literature by Pelouze in 1831. He precipitated hydrated carbonate from a solution of lime, sugar and water. Pelouze noted that crystals precipitated in the solution although the sugar did not dissolve, from which he interpreted that $\mathrm{CO}_{2}$ from the air was sufficient to form the calcium carbonate hydrates. The crystals were more abundant and larger at lower temperature and he noted that the crystals decomposed above $+30^{\circ} \mathrm{C}$ and that below $+20^{\circ} \mathrm{C}$ the crystals were preserved without alteration in air or water. He further noted that the density of the crystals was 1.78 and when heated to $100^{\circ} \mathrm{C} 47 \%$ of the volume was lost as water. From these observations, Pelouze suggested that the carbonate contained 5 molecules of water (Pelouze, 1831).

Johnston et al. (1916) wrote in their "Compilation of several forms of calcium carbonate" that they precipitate calcium carbon hexahydrate by slowly dropping $1 \mathrm{~L}$ of $0.1 \mathrm{M} \mathrm{K}_{2} \mathrm{CO}_{3}$ and $1 \mathrm{~L}$ of $0.1 \mathrm{M} \mathrm{CaCl}_{2}$ into a beaker that was surrounded by ice and contained $2 \mathrm{~g}$ of $\mathrm{KOH}$. The only hydrated calcium carbonate encountered in their experiments was the calcium carbonate hexahydrate which precipitated as colourless monoclinic crystals. When heated the residue weight was $48.03 \%$ of the weight of the mineral before heating. They also found that the hexahydrate changed rapidly to calcite and water at room temperature, this also occurred at temperature down to $0^{\circ} \mathrm{C}$ but at a slower rate. Johnston et al. (1916) hypothesised that the hexahydrate precipitated in nature, especially in the presence of seawater, but that it had not been found due to its instability. 
As hypothesised by Johnston et al. (1916), the calcium carbonate hexahydrate was discovered in nature 50 years later by Pauly (1963) in a shallow fjord in southwest Greenland. At this site, several hundred tufa columns rise from the bottom of the fjord. The columns are up to $20 \mathrm{~m}$ high and their diameters range from a few centimetres to several meters. The columns are composed of calcium carbonate hexahydrate. Pauly named the mineral ikaite after the Ikka fjord where it was found (fig. 1).

Ikaite is monoclinic and in its structure, $\mathrm{Ca}^{2+}$ and $\mathrm{CO}_{3}{ }^{2-}$ form an ion pair, which is isolated from other ion pairs by an envelope of 18 water molecules. Six of these water molecules are bonded to the Ca (Dickens and Brown, 1970). These authors found ikaite density to be $1.82 \mathrm{~g} \mathrm{~cm}^{-3}$ at $0^{\circ} \mathrm{C}$. Marland (1975) constrained the stability field of ikaite, calcite and aragonite in the system $\mathrm{CaCO}_{3}-\mathrm{H}_{2} \mathrm{O}$ (fig. 2). Ikaite is stable at $25^{\circ} \mathrm{C}$ at a minimum pressure of $508 \mathrm{MPa}$; conditions which do not exist on planet Earth. For this reason, ikaite only occurs metastably in nature.


Figure 1. Above is a map showing the location of Ikka Fjord. Modified after Buchardt et al. (2001). To the left ikaite column appears at the water surfaces in Ikka Fjord. Photo: Richard Martin / www.coldzymes.dk

For several years, Ikka Fjord was the only place where ikaite had been found in nature. The next time ikaite was discovered in nature was in 1982, when large crystals of the mineral were found in anoxic, organic-rich sediments from the Antarctic Shelf (Suess et al., 1982). The authors linked ikaite to a well-known calcite pseudomorph, glendonite, which was frequently found in association with glacial marine deposits. Because of its similar formation environment, mineral shape and depleted $\delta^{13} \mathrm{C}$ value (indicating organic matter as the carbon source), ikaite was considered to be the precursor of glendonite. These 
findings opened the possibility to use glendonite pseudomorphs as a paleoclimate indicator because the precursor, ikaite, only can form at temperatures near $0^{\circ} \mathrm{C}$ at normal pressure.

The physical properties of the mineral ikaite were further studied in several experiments (Swainson et al. 2001; Lennie et al. 2004; Lennie, 2005). Swainson et al. (2001) investigated the crystallography of ikaite and could confirm the link to the pseudomorphs "glendonites". Lennie (2005) found that the compressibility of ikaite is greater than that of gypsum, calcite and aragonite and that ikaite shows no evidence of phase transformation in experiments run at pressures up to $4 \mathrm{GPa}$. Lennie (2005) also showed that dissolution of $\mathrm{CaCO}_{3}$ in $\mathrm{H}_{2} \mathrm{O}$ at high pressure results in crystallization of ikaite which therefore suggests equilibrium behaviour between carbonate-rich fluid species and ikaite.

In 2008, ikaite crystals were reported in natural sea ice from Antarctic (Dieckmann et al. 2008) and in Arctic sea ice in 2010 (Dieckmann et al. 2010). These findings could indicate that ikaite is part of the carbon cycle in the atmosphere-ocean-sea ice system in polar regions (Geilfus et al. 2013).

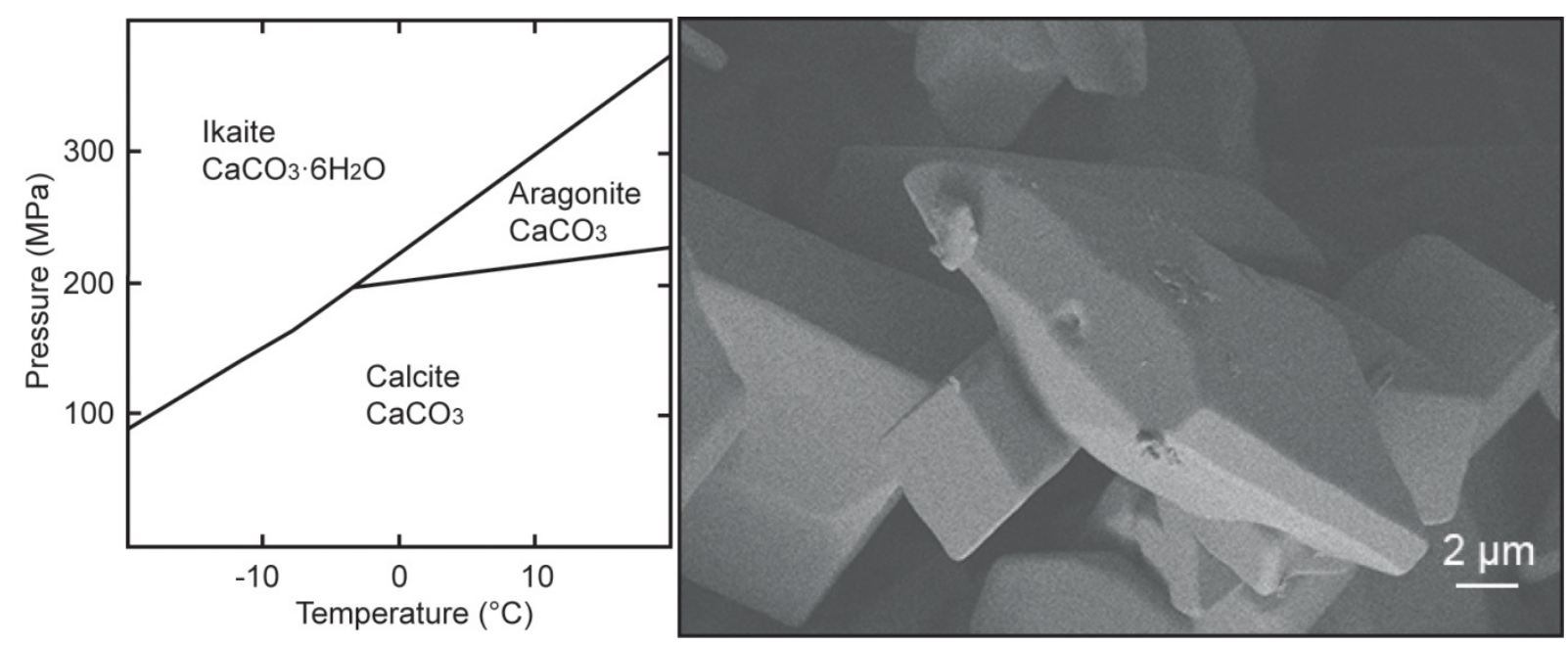

Figure 2. To the left stability field for calcite, aragonite and ikaite in the system $\mathrm{CaCO}_{3}-\mathrm{H}_{2} \mathrm{O}$. Modified after Marland (1975). To the right cryo SEM image of ikaite crystals.

\subsection{Formation environments}

In nature, ikaite has been found in three types of environment so far; 1) as a direct precipitate from a mixture of spring water and seawater, as in Ikka Fjord, or a mixture of spring water and alkaline lake water, as in Mono Lake (Buchardt et al. 2001; Bischoff et al., 1993b; Council and Benett, 1993); 2) in sediments (Suess et al., 1982; Schubert et al., 
1997); and 3) in sea ice (Dieckmann et al., 2008; Dieckmann et al., 2010). All three of these environments of formation are characterised by low temperatures.

When ikaite precipitates from a mixture of two solutions as in Ikka Fjord and Mono Lake, the mixed solution is supersaturated with respect to calcium carbonates, but for some reason calcite does not precipitate. In Mono Lake, the precipitation of ikaite has been observed as a seasonal feature where ikaite precipitates during cold winters. During the warmer periods, ikaite does not precipitate, even though the mixture is supersaturated. This clearly suggests that calcite growth is inhibited but that ikaite growth is not affected by the inhibitor (Bischoff et al., 1993b; Council and Benett, 1993).

There are two processes suggested for marine, sedimentary ikaite formation: 1) organotrophic sulfate reduction observed in sediments with fresh ikaite crystals and 2) methanotrophic sulfate reduction or anaerobic oxidation of methane (Teichert and Luppold, 2013). In the first of these processes, high carbonate alkalinity was produced by degradation of organic matter by sulfate reduction, which favoured ikaite precipitation (Suess et al., 1982). In the second of these processes, ikaite found in sediments on the Siberian shelf with very low $\delta^{13} \mathrm{C}$ values are indicative of a methane source (Schubert et al., 1997).

When young sea ice starts to form, there is a build-up of salinity and increase in $\mathrm{pH}$ in the top layers. This causes some salts to reach their solubility threshold and start to precipitate. However, it is unclear if this type of process can account for ikaite precipitation in sea ice (Geilfus et al. 2013).

\subsection{Ikaite pseudomorphs}

A group of pseudomorphs ranging in size from $<1 \mathrm{~cm}$ to nearly $1 \mathrm{~m}$ and mostly composed of calcite was first described by Friesleben, a German mineralogist, in 1827 and then extensively described by Dana (1884). The precursor of these pseudomorphs has been an enigma for several decades and was not identified until 1982 when Suess et al. (1982) found fresh ikaite in sediment cores and linked them to the pseudomorphs glendonite (Fig 3. (37)).

The pseudomorphs have been given various names related to their localities, the best known are thinolites (Fig. 3 (6, 2)), glendonites (Fig. 3 (37)), gersternkörner (Fig. 3 (26, 31)) and jarrowites (Shearman and Smith 1985, Huggett et al. 2005). Thinolites represents pseudomorphs of ikaite tufas that grew over springs and precipitated in lake water as in Mono Lake, whereas glendonites, gersternkörner and jarrowites are pseudomorphs of 
ikaite found in sediments (Huggett et al. 2005). The change from ikaite to calcite implies a volume reduction of $68.6 \%$ if ikaite decompose to calcite with no loss of $\mathrm{Ca}$ and $\mathrm{CO}_{3}$ ions (Shearman and Smith 1985). Some Quaternary pseudomorphs are very porous with void ratios up to $69 \%$, whereas older samples of pseudomorphs often show up to three generations of calcite and no porosity (Shearman and Smith 1985). Glendonites have recently been used to track ancient methane seepage in polar seas by looking at authigenic carbonates associated with anaerobic oxidation of methane (Morales et al. 2017).

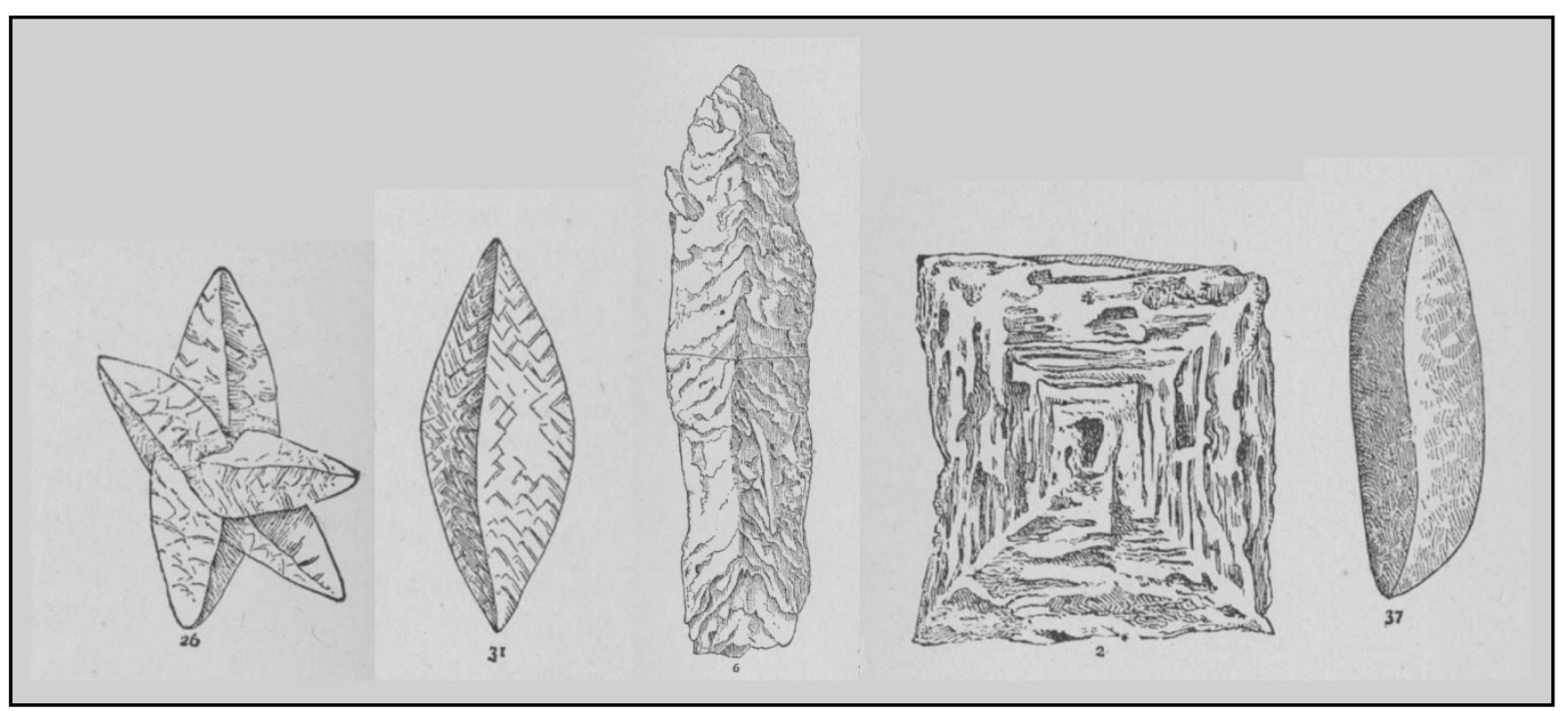

Figure 3. Selected drawings of pseudomorphs not to scale by Dana (1884). From left to right gersternkörner from Sangenhausen, Thuringia (26, 31), thinolites from Pyramid Lake, Nevada (6, 2) and glendonite from New South Wales, Australia (37).

\section{Ikka Fjord}

\subsection{Site description}

Ikka Fjord is situated in south west Greenland, it is a $13 \mathrm{~km}$ long and up to $1.6 \mathrm{~km}$ wide glacial valley (Buchardt et al., 2001; Fig. 1). The climate in the area is low arctic, i.e. snow and ice generally cover Ikka Fjord from November to May, mean annual temperatures are between $-1.9^{\circ} \mathrm{C}$ and $+2.9^{\circ} \mathrm{C}$ and annual precipitation is $\sim 1000 \mathrm{~mm}$ (Buchardt et al., 2001; Ohumara and Reeh, 1991; Hansen et al., 2011). In the upper and shallowest part of the fjord, more than 700 columns rise from the bottom of the fjord. The age of the columns is unknown but they must post-date the last glaciation period during which the fjord was icefilled. In a legend told by the Inuit, the columns were seen as dead Norsemen standing at the bottom of Ikka Fjord (Rink 1866). When Pauly (1963) investigated the columns, he mentioned that they were known of for several years. 
The fjord is surrounded by up to $500 \mathrm{~m}$ high mountain plateaus. All the columns are located below the Grønnedal-Íka complex (Fig. 4) which comprises several series of nepheline syenites and a carbonatite plug (Emeleus 1964). This igneous body intruded the Archean bedrock during a period of continental rifting referred to as the Gardar episode which took place 1.3 billion years ago (Upton et al. 2003).
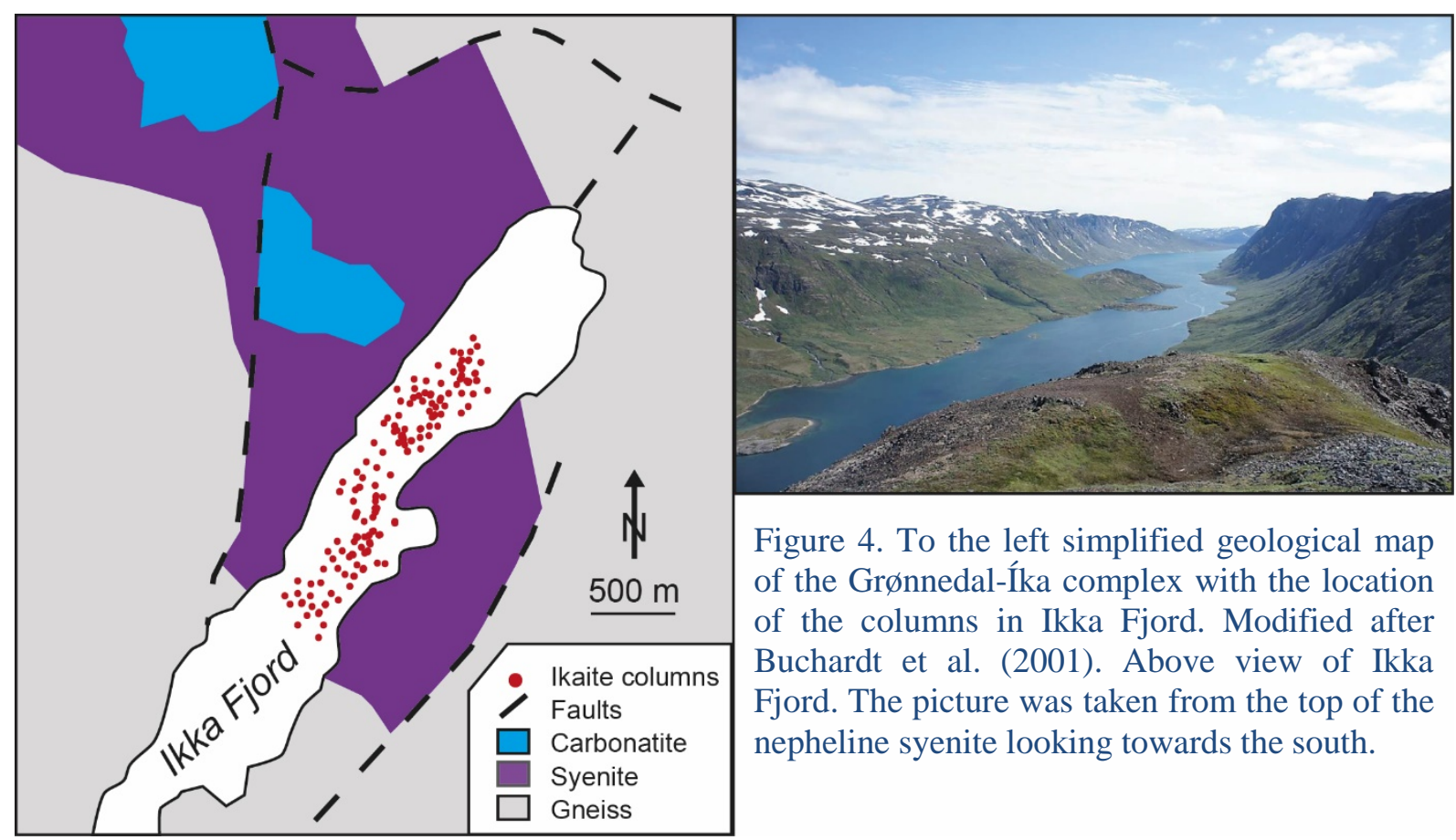

Figure 4. To the left simplified geological map of the Grønnedal-Íka complex with the location of the columns in Ikka Fjord. Modified after Buchardt et al. (2001). Above view of Ikka Fjord. The picture was taken from the top of the nepheline syenite looking towards the south.

\subsection{Column formation}

Ikaite forms when carbonated spring water seeping up at the bottom of the fjord comes in contact with seawater (Fig. 5). The rate of precipitation is high, and the columns can grow up to $0.5 \mathrm{~m} /$ year (Buchardt et al., 2001). Because the density of the spring water is lower than the density of seawater and because the columns are porous, the spring water rises as the columns grow until they reach the halocline $\sim 4 \mathrm{~m}$ below the water surface (Hansen et al., 2011). The mixture of spring water and seawater is milky in appearance and supersaturated with respect to calcite, aragonite and ikaite (Buchardt et al., 2001). The composition of the spring water reflects water-rock interaction in the Grønnedal-Íka complex within which meteoric water percolates along fractures and reacts with minerals in the bedrock. The nepheline syenites are rich in feldspar, nepheline, pyroxene and biotite, and the carbonatite in calcite and smaller amount of siderite and apatite (Emeleus, 1964). It 
is likely that reactions involving mainly nepheline, calcite, siderite and apatite lead to the high concentrations of $\mathrm{Na}^{2+}(170-198 \mathrm{mmol} / \mathrm{L}), \mathrm{PO}_{4}{ }^{3-}(0.093-0.26 \mathrm{mmol} / \mathrm{L})$ and total C $(67$ - $96 \mathrm{mmol} / \mathrm{L}$ ) in the spring water (Buchardt et al. 2001), which explains why all the columns are located below the complex. The spring water has very low concentrations of Ca (0.09 - $0.24 \mathrm{mmol} / \mathrm{L})$ which implies that Ca from calcite must be lost inside the igneous complex to secondary mineral precipitation. $\mathrm{PO}_{4}$ is known to inhibit calcite precipitation from experiments (Burton and Walter, 1990) and therefore, Buchardt et al. (2001) suggested the high concentrations $\mathrm{PO}_{4}$ as one of the reasons why ikaite precipitated in Ikka Fjord.
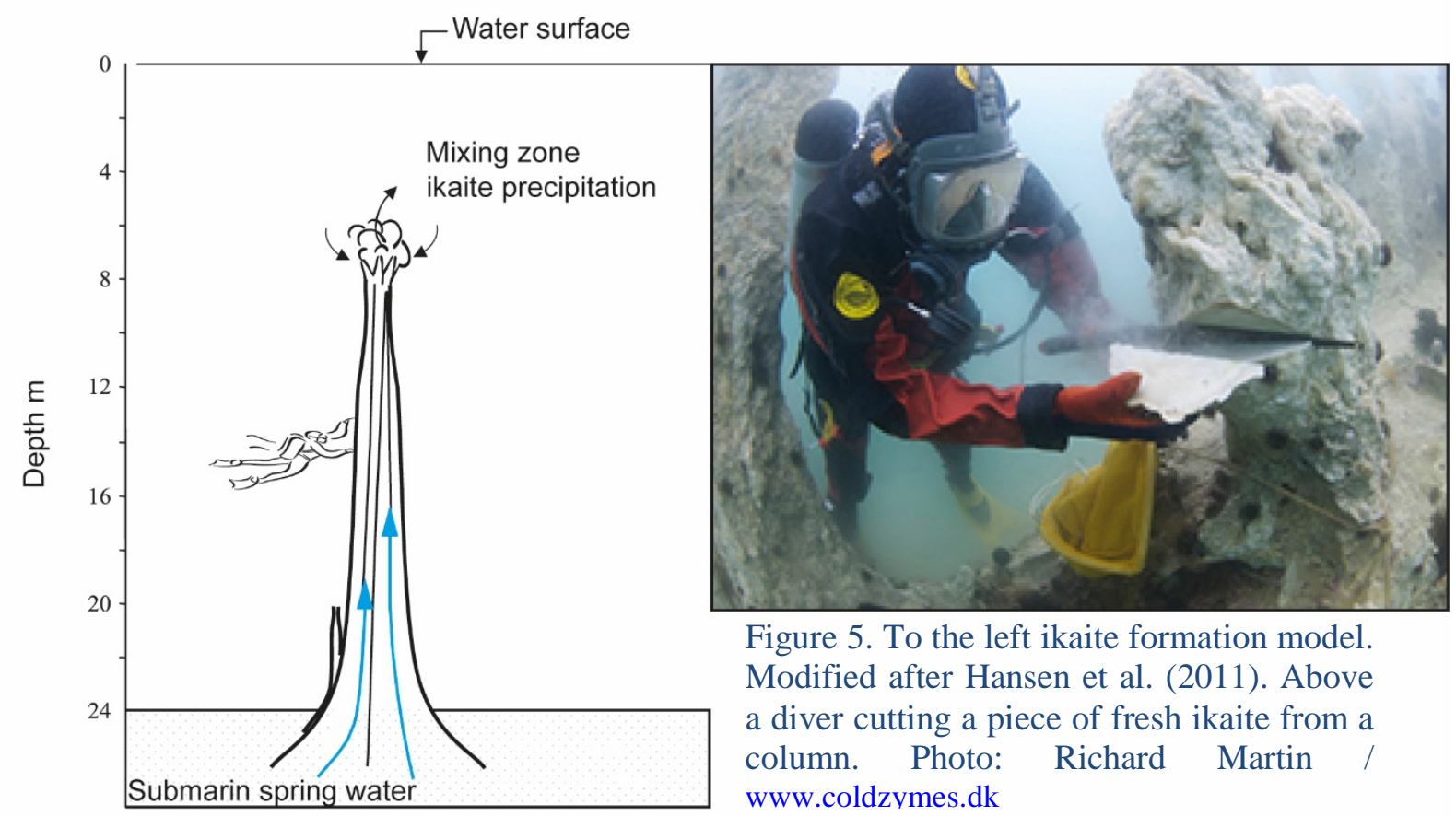

Figure 5. To the left ikaite formation model. Modified after Hansen et al. (2011). Above a diver cutting a piece of fresh ikaite from a column. Photo: Richard Martin / www.coldzymes.dk

Ikka Fjord was monitored and investigated during several seasons from 1995 to 2013 (Buchardt et al., 2001; Dahl and Buchardt, 2006; Hansen et al., 2011; Trampe et al., 2016). The columns are rooted in soft sediments, at the sides of rock exposures or as dome-like shapes. Columnar debris surrounds many of the columns (Buchardt et al., 2001). The fresh columns are mainly composed of ikaite whereas the debris are dominated by monohydrocalcite $\left(\mathrm{CaCO}_{3} \cdot \mathrm{H}_{2} \mathrm{O}\right)$, calcite and minor amounts of aragonite and hydrous Mg-carbonates (Dahl and Buchardt, 2006). The columns are hosts for a diverse flora and fauna of algae and invertebrates, which also are thought to protect the columns from dissolving in the seawater. (Buchardt et al., 2001; Trampe et al., 2016). 


\section{Calcium carbonates}

Ikaite forms in environments which are supersaturated with respect to calcium carbonates. There are five types of crystalline calcium carbonates found in nature, three of which are anhydrous and two of which are hydrous. There is also an amorphous form of calcium carbonate, but this will not be discussed in this thesis.

\subsection{Anhydrous $\mathrm{CaCO}_{3}$}

The most common calcium carbonate minerals are calcite and aragonite. Vaterite is a third polymorph of $\mathrm{CaCO}_{3}$ which also occurs in nature, but is much rarer. The reason why the two common polymorphs: calcite and aragonite exist is that the radius of the calcium ion is close to the limiting value for the transition between the rhombohedral (calcite) structure and the orthorhombic (aragonite) structure (Deer et al. 1992). However, calcite is the stable form of $\mathrm{CaCO}_{3}$ at surface conditions (Fig. 2) and is an important rock-forming mineral which can be primary or secondary in sedimentary, metamorphic and igneous rocks. Aragonite is less common than calcite. Aragonite is found as a primary precipitate in seawater, as a replacement mineral and as a metamorphic mineral in some low temperature blueschist facies rocks (Deer et al. 1992). Both calcite and aragonite can be precipitated by organisms in the oceans. The solubility of all the anhydrous $\mathrm{CaCO}_{3}$ minerals increases with decreasing temperature and increasing $\mathrm{CO}_{2}$ pressure (Bischoff et al., 1993a; Deer et al., 1992). This is observed in the oceans when skeletal carbonate sinks and dissolves before reaching the bottom, provided that this is beneath the carbonate compensation depth (CCD). Calcite dissolves readily in weak acid, and chemical weathering of limestone and other bedrock types containing large amounts of calcite, creates a karst landscape and sinkholes. In the same way that calcite dissolves easily it also precipitates easily and it is therefore common as a cement in sedimentary rocks, in veins and as secondary mineral.

Calcite is generally relatively pure but some substitutions can occur, the most common of which is the accommodation of $\mathrm{Mg}$ in its structure. This has led to the terms low-Mg calcite $\left(<4 \mathrm{~mol} \% \mathrm{MgCO}_{3}\right)$, intermediate-Mg calcite (4-12 mol \% $\left.\mathrm{MgCO}_{3}\right)$ and high-Mg calcite (> $12 \mathrm{~mol} \% \mathrm{MgCO}_{3}$ ). The incorporation of $\mathrm{Mg}$ in calcite is thought to reflect seawater temperatures and the $\mathrm{Mg} / \mathrm{Ca}$ ratio of ancient and recent seawater (Veizer 1992).

In the oceans, calcite and low Mg-calcite precipitation versus aragonite and high Mgcalcite precipitation oscillated through geological time (Sandberg 1983), possibly due to 
secular variation in $\mathrm{Mg} / \mathrm{Ca}$ ratio in the seawater which is driven by fluctuations in seafloor spreading rates (Hardie, 1996; Stanley et al., 1999; Lowenstein et al., 2001).

\subsection{Hydrous $\mathrm{CaCO}_{3}$}

There are two types of hydrated calcium carbonate found in nature. In addition to ikaite, monohydrocalcite $\left(\mathrm{CaCO}_{3} \cdot \mathrm{H}_{2} \mathrm{O}\right)$ can also occur. Monohydrocalcite (MHC) is rare in nature but has been found in several environments of which the most common is saline alkaline lakes. MHC is, as ikaite, metastable, but water temperature is not important for the formation of MHC. However, it has been observed in experiments that MHC forms in the presence of Mg (Nishiyama et al., 2013; Rodriguez-Blanco et al., 2014).

\section{Kinetics}

The laws of thermodynamics tell us that a reaction will proceed if the product of the reaction is more stable (e.g. has a lower energy state) than the reactant, i.e. the change of free energy $(\Delta G)$ of the reaction is negative, but these laws do not tell us about the rate at which a reaction will occur and/or the path the reaction will take. Kinetics is about the rate and path of a reaction. The rate of a reaction can range from a fraction of a second to millions of years. Temperature has a strong influence on the rate of reactions; higher temperatures increase the reaction rate. The presence of a catalyst can allow a system to take an easier path which requires lower activation energy and the reaction will proceed faster. Inhibitors, on the other hand, can slow a reaction or prevent it from occurring (Lasaga, 2014). In Ikka Fjord, metastable ikaite precipitates instead of stable calcite. The temperature in Ikka Fjord is low which could disadvantage calcite, favouring ikaite precipitation. Also, the presence of substances which inhibit calcite formation, might promote ikaite formation instead.

\subsection{Calcite inhibitors}

From experiments, phosphate is known to inhibit calcite growth if its concentration exceeds $5 \mu \mathrm{mol} / \mathrm{kg}$ (Burton and Walter, 1990). This is caused by rapid adsorption of $\mathrm{PO}_{4}$ on the surface of calcite and thereby new growth of calcite is blocked (Burton and Walter, 1986). Lin and Singer (2006) found that the inhibition of calcite by phosphate was more efficient at lower $\mathrm{pH}$.

Magnesium is another known inhibitor of calcite growth (Berner, 1975; Davis et al., 2000). Berner (1975) showed in experiments the effect of $\mathrm{Mg}$ in seawater on calcite and 
aragonite growth. Aragonite growth was relatively unaffected by Mg, whereas calcite was strongly inhibited by Mg. The Mg was readily adsorbed on to the surface of calcite and incorporated into the crystal structure (Berner, 1975). Further experiments by Davis et al. (2000) showed that the incorporation of $\mathrm{Mg}$ into the $\mathrm{CaCO}_{3}$ lattice results in an increase of mineral solubility which could be the cause of reduced calcite growth.

Sulfate has also been found to inhibit calcite growth (Mucci et al., 1989; Bots et al., 2011). Mucci et al., (1989) showed in their experiments that the presence of $\mathrm{SO}_{4}$ decreased the precipitation rate of calcite and a Mg-bearing overgrowth was formed. Nielsen et al. (2016) tested the combined effects of $\mathrm{Mg}$ and $\mathrm{SO}_{4}$ and found that $\mathrm{Mg}$ inhibition of calcite was more effective in the presence of $\mathrm{SO}_{4}$.

\section{Previous experimental work}

As stated previously, ikaite was synthesised experimentally before it was discovered. After its discovery, experiments aimed at understanding the controls of metastable ikaite precipitation in nature were conducted. Experiments conducted by Bischoff et al. (1993a) tested the solubility of ikaite from $0^{\circ}$ to $25^{\circ} \mathrm{C}$. They found that $\mathrm{PO}_{4}$ stabilized ikaite and thereby prevented the formation of anhydrous $\mathrm{CaCO}_{3}$. Their conclusion was that the presence of ikaite or its pseudomorphs is an indicator of environment with high concentrations of $\mathrm{PO}_{4}$ (Bischoff et al. 1993a). However, Rodriguez-Ruiz et al. (2014) precipitated and stabilized ikaite in confined nano- and picovolumes at $20^{\circ} \mathrm{C}$ without inhibitors. Other recent experimental studies have focused on ikaite precipitation in sea ice; $\mathrm{Hu}$ et al. (2014a) studied ikaite precipitation as a function of $\mathrm{pH}$, salinity and phosphate concentration. They found that $\mathrm{pH}$ was the controlling factor on ikaite precipitation and $\mathrm{PO}_{4}$ had no impact on ikaite precipitation. Stockmann et al. (2016) simulated Ikka Fjord conditions to test the effect of $\mathrm{PO}_{4}$ on ikaite precipitation. They were able to precipitate ikaite without $\mathrm{PO}_{4}$ at temperatures from $5^{\circ}$ to $15^{\circ} \mathrm{C}$ implying that $\mathrm{PO}_{4}$ was not needed for ikaite precipitation to be favoured. They suggested that another inhibitor like Mg and/or $\mathrm{SO}_{4}$ was probably preventing calcite from precipitating and thereby favouring ikaite.

\section{Methods}

\subsection{Experimental setup}

The experiments were setup at the Department of Geological Sciences with the aim to test the chemical control of $\mathrm{Mg}, \mathrm{SO}_{4}$ and $\mathrm{pH}$ on ikaite formation under simulated Ikka Fjord 
conditions. The experimental method used was the same as for the experiments conducted by Stockmann et al. (2016) except for some modifications in the filtering process used to recover the precipitates. The synthetic spring water (hereafter referred to as Ikka water) was mixed with natural seawater, synthetic seawater or synthetic seawater with $\mathrm{SO}_{4}$ or $\mathrm{Mg}$ removed at a constant rate regulated by a peristaltic pump and at a constant temperature of $5.0 \pm 0.2^{\circ} \mathrm{C}$ (Fig. 6). Each experiment took 5 to 6 hours. After the experiment was stopped the mixture that was obtained was kept in a $5^{\circ} \mathrm{C}$ cold room and filtered the next day with Munktell 00K filter. The precipitate on the filter was dried overnight in the cold room and thereafter collected and weighted before being transferred to a freezer $\left(-18^{\circ} \mathrm{C}\right)$ for storage.

\subsubsection{Geochemical modelling}

Geochemical modelling of all the experiments was performed with PhreeqC Interactive version 3.3.0 (Parkhurst and Appelo, 2013) to verify the saturation index (SI) of calcium carbonates and magnesium carbonates in the mixed solution. Where SI $=\log \left(\mathrm{IAP} / \mathrm{K}_{\mathrm{sp}}\right)$, and IAP stands for Ion Activation Product and $\mathrm{K}_{\mathrm{sp}}$ for solubility product.

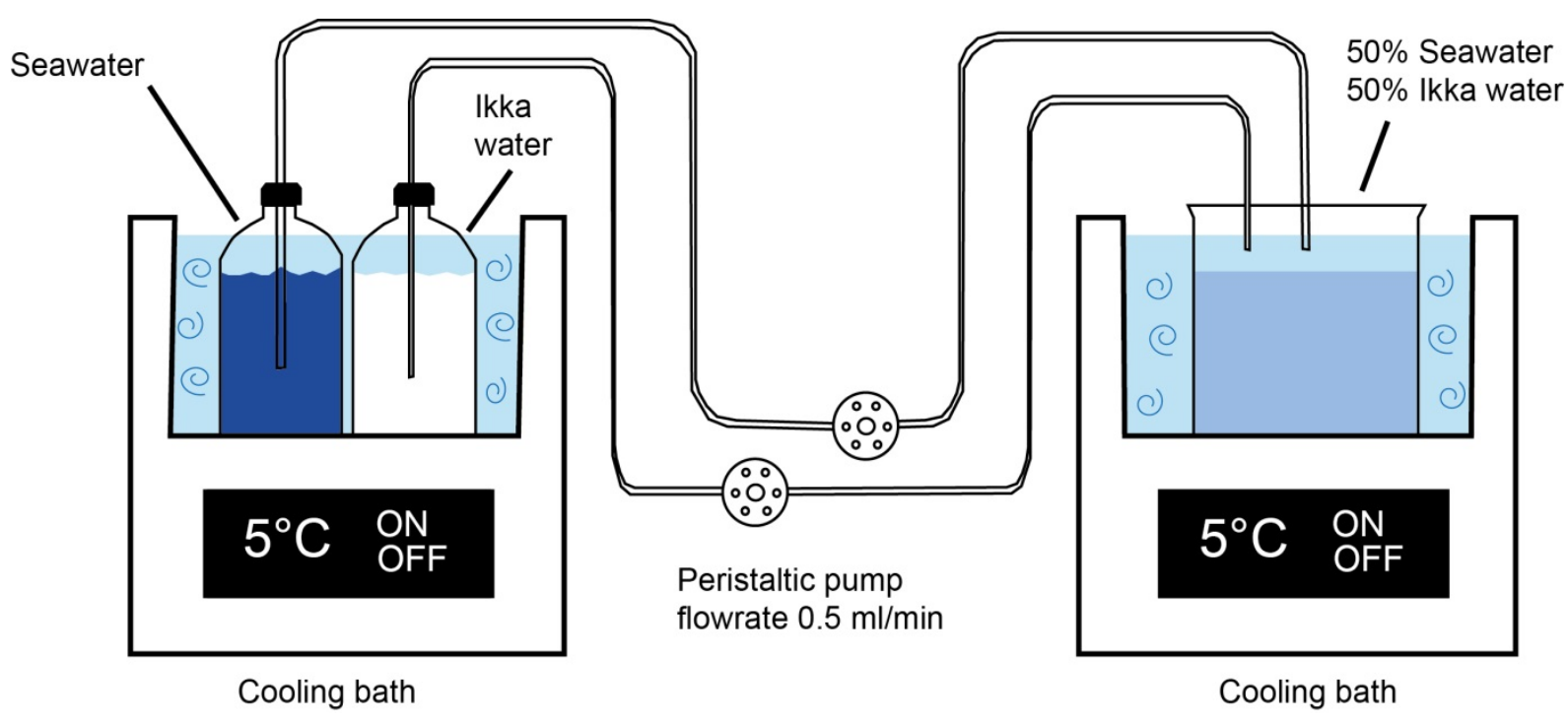

Figure 6. The experimental setup in laboratory. A flask of natural or synthetic seawater and Ikka water were kept in one cooling bath. The two solutions were pumped into a beaker in a second cooling bath. Modified after Stockmann et al. (2016)

\subsubsection{Seawater}

The natural seawater used was collected outside Andøya in Norway. The seawater was filtered before use. The conductivity, salinity and ion concentrations were analysed at the 
Department of Environmental Science and Analytical Chemistry (ACES) and at the Department of Geological Sciences, Stockholm University. Synthetic seawater was made to replicate average natural seawater based on ion concentrations listed in Stumm and Morgan (1996). $\mathrm{Mg}$ or $\mathrm{SO}_{4}$ was removed from (i.e. not added to) the synthetic seawater in some experiments and the Mg concentrations were varied in other experiments.

\subsubsection{Ikka water}

The synthetic Ikka water was prepared according to the method used by Stockmann et al. (2016) as follows: Ikka water found in Ikka Fjord was simulated by a mixture of $0.1 \mathrm{M}$ $\mathrm{Na}_{2} \mathrm{CO}_{3}$ and $0.1 \mathrm{M} \mathrm{NaCO}_{3}$ in ratios $1: 1,3: 1$ and 4:1, which gave a $\mathrm{pH}$ of $10.1,10.6$ and 10.7 respectively at $5^{\circ} \mathrm{C}$. To test the effect of $\mathrm{pH}$ on ikaite precipitation the ratios were extended beyond those found in Ikka Fjord to 1:15 to 1:0 which covered a range of $\mathrm{pH}$ from 9.1 to 11.8 at $5^{\circ} \mathrm{C}$.

\subsection{XRD}

The precipitates from the experiments were identified with X-ray diffraction (XRD) at the Swedish Museum of Natural History in Stockholm. The instrument used was an X Pert Pro from PANalytical with the program Data Colllector. To preserve the ikaite crystals the sample supporter was put into a freezer $\left(-18^{\circ} \mathrm{C}\right)$ for $10 \mathrm{~min}$ before analysis and a relatively short measurement program was used from Absolute Scan 5-70 with a runtime of $11 \mathrm{~min}$. Mineral identification and quantification (Rietveld refinement) of the phases was done with the program HighScore Plus version 3.0 and version 4.6a. XRD is one of the most reliable mineral identification methods; however it was not possible to distinguish calcite from low Mg-calcite as the structure of these two minerals are too similar.

\subsection{SEM-imaging}

Scanning Electron Microscope (SEM) imaging was used to visualise the mineral shapes from some precipitates. To preserve the ikaite crystals cryo-SEM was used. The instrument was a Carl Zeiss Merlin Field-Emission Scanning Electron Microscope (FESEM) using Quorum Technologies PP3000T Cryo Preparation System at Umeå University. For one sample with calcite an Environmental Scanning Electron Microscope with Field Emission Gun of the brand Philips XL-30- ESEM-FEG was used at Stockholm University. 


\section{Results and conclusions}

Six series of experiments were conducted to test the controlling factors of $\mathrm{Mg}, \mathrm{SO}_{4}$ and $\mathrm{pH}$ on synthetic ikaite precipitation. In total this comprises 47 experiments of which 10 were duplicates. The results, discussion and conclusions of these experiments are presented in the manuscript, and a short summary is presented here.

The first series of experiments were designed to test the effect of $\mathrm{SO}_{4}$ and $\mathrm{Mg}$ on ikaite precipitation by removing these elements from the synthetic seawater. Ikaite precipitated in experiments with natural seawater, synthetic seawater and synthetic seawater with $\mathrm{SO}_{4}$ removed, whereas calcite precipitated in experiments with synthetic seawater with Mg removed. The second to sixth series of experiments were designed to find threshold for ikaite precipitation by varying two parameters; Mg concentration in seawater and $\mathrm{pH}$ in Ikka water.

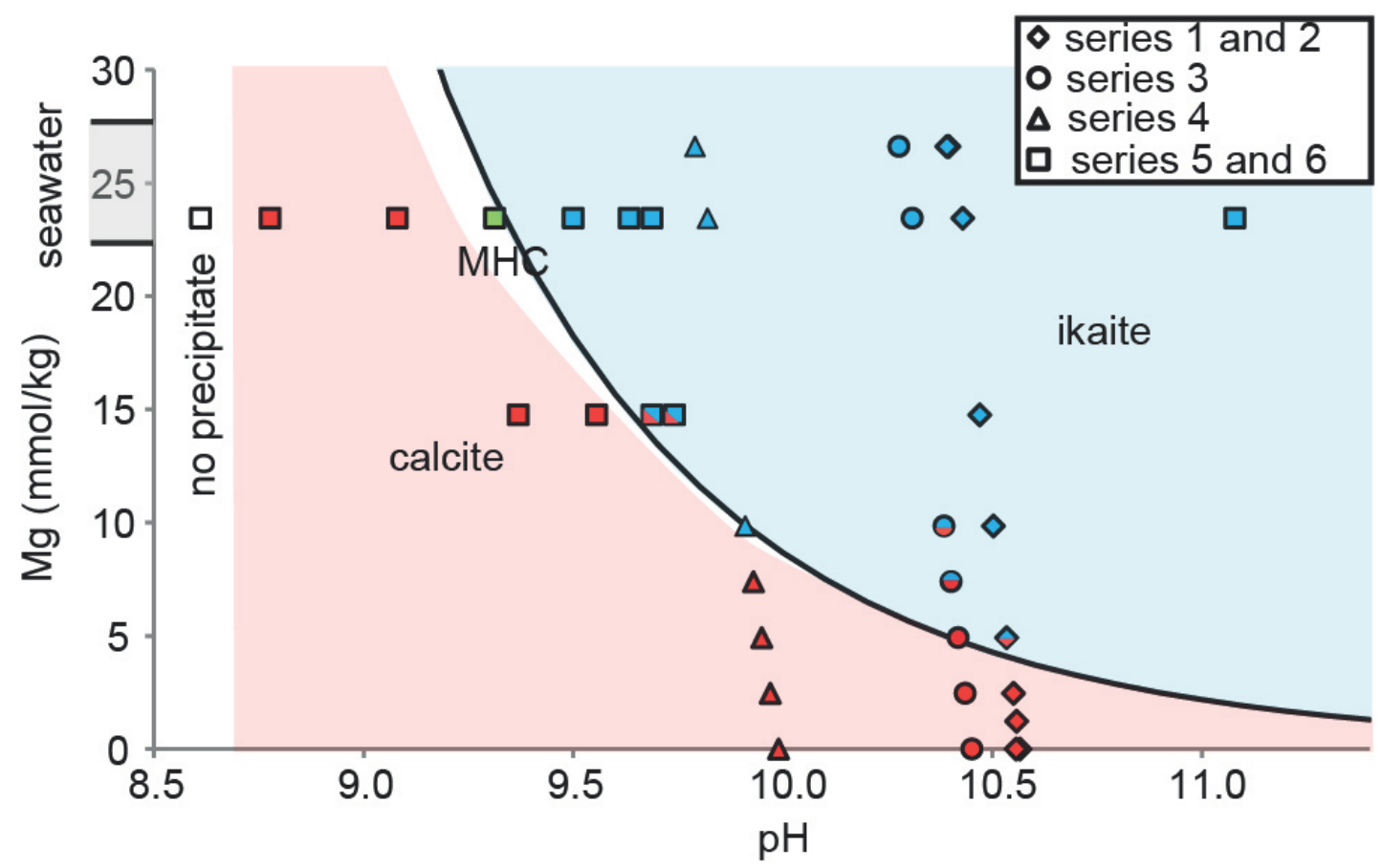

Figure 7. Kinetic stability diagram for ikaite and calcite precipitation as a function of $\mathrm{pH}$ and $\mathrm{Mg}$ concentration in solution at $5^{\circ} \mathrm{C}$. The blue symbols represent ikaite precipitations, the red symbols calcite precipitation and the green symbol monohydrocalcite (MHC).

Ikaite was found to precipitate at $\mathrm{pH}>9.3$ with high $\mathrm{Mg}$ concentration (22.8 $\mathrm{mmol} / \mathrm{kg}$ ). Ikaite did also precipitate at lower Mg concentration (4.92 mmol/kg) with high $\mathrm{pH}$ (10.5). By combining the results from the experiments a kinetic stability diagram for 
ikaite and calcite precipitation was constructed as a function of $\mathrm{pH}$ and $\mathrm{Mg}$ concentration at $5^{\circ} \mathrm{C}$ (Fig. 7).

The conclusion of this study is that the $\mathrm{pH}$ of the Ikka water and $\mathrm{Mg}$ concentration in the seawater control ikaite formation in Ikka Fjord. Ikaite precipitation is favoured by high $\mathrm{pH}$, high Mg concentration, probably reflecting inhibition of calcite formation by Mg. This study contributes to broaden the understanding of ikaite precipitation which has implication for carbon sequestration given the rapidity at which ikaite form.

\section{Future work}

\subsection{Low temperature alteration in Grønnedal-Íka igneous complex}

A petrographic and geochemical study of rock samples collected during field work in Grønnedal-Íka igneous complex in 2014 is being conducted to investigate the alteration of minerals in the complex. The aim of this study is to correlate the alteration in the complex to the chemical composition of the Ikka water so as to fully understand the formation process of the columns in Ikka Fjord.

\subsection{Ikaite pseudomorphs in Neoproterozoic dolostones on Islay, Scotland}

A petrographic and geochemical study of pseudomorphs found in dolostones on Islay will be conducted. The aim of this study is to unravel the formation and deformation history of the pseudomorph.

\section{Acknowledgements}

First of all I would like to thank my supervisor Alasdair Skelton for encouraging support. I also thank Gabrielle Stockmann who initiated the project. Thanks to my co-supervisors Magnus Mörth and Erik Sturkell. Thank you to the Bolin Centre for their financial support. Thanks to all the people who assisted me with lab work Marianne Ahlbom, Volker Brüchert, Christophe Dupraz, Jörgen Ek, Pär Hjelmqvist, Jörgen Langhof, Cheng Choo Nikki Lee, Jayne Rattray, Henrik Skogby, Malin Söderman and Johannes West. I also want to thank the staff at the Department of Geological Sciences, my friends and my family.

\section{References}

Berner, R. A. (1975). The role of magnesium in the crystal growth of calcite and aragonite from sea water. Geochimica et Cosmochimica Acta, 39(4), 489IN3495-494504. 
Bischoff, J.L., Fitzpatrick, J.A., and Rosenbauer, R.J., 1993a, The solubility and stabilization of ikaite $\left(\mathrm{CaCO}_{3} \cdot 6 \mathrm{H}_{2} \mathrm{O}\right)$ from $0^{\circ}$ to $25^{\circ} \mathrm{C}$ : Environmental and paleoclimatic implications for Thinolite Tufa. Journal of Geology, v. 101, p. 21-33.

Bischoff, J. L., Stine, S., Rosenbauer, R. J., Fitzpatrick, J. A., \& Stafford Jr., T. W. 1993b: Ikaite precipitation by mixing of shoreline springs and lake water, Mono Lake, California, USA. Geochimica et Cosmochimica Acta 57, 3855-3865.

Bots, P., Benning, L.G., Rodriguez-Blanco, J.D., Roncal-Herrero, T., and Shaw, S., 2012, Mechanistic insights into the crystallization of amorphous calcium carbonate (ACC). Crystal Growth \& Design, v. 12, p. 3806-3814, doi: 10.1021/CG300676b.

Buchardt, B., Israelson, C., Seaman, P., and Stockmann, G., 2001, Ikaite tufa in Ikka Fjord, southwest Greenland: Their formation by mixing of seawater and alkaline spring water. Journal of Sedimentary Research, v. 71, p. 176-189.

Burton, E.S., and Walter, L.M. 1986, The effect of orthophosphate on carbonate mineral dissolution rates in seawater. Chemical Geology, v. 56, p. 313-323.

Burton, E. A., \& Walter, L. M. (1990). The role of pH in phosphate inhibition of calcite and aragonite precipitation rates in seawater. Geochimica et Cosmochimica Acta, 54(3), 797-808.

Council, T.C., and Bennett, P.C., 1993, Geochemistry of ikaite formation at Mono Lake, California: implications for the origin of tufa mounds, Geology, v. 21, p. 971-974.

Davis, K. J., Dove, P. M., \& De Yoreo, J. J. (2000). The role of Mg2+ as an impurity in calcite growth. Science, 290(5494), 1134-1137.

Dahl, K., and Buchardt, B., 2006, Monohydrocalcite in the Arctic Ikka Fjord, SW Greenland: First Reported Marine Occurrence. Journal of Sedimentary Research v. 76, p. 460-471.

Dana, E. S. 1884. A crystallographic study of the thinolite of Lake Lahontan. U.S. Geological Survey Bulletin No. 12, 429-50.

Deer, W. A., Howie, R. A., and Zussman, J., 1992. An Introduction to the Rock Forming Minerals, 2nd ed., Longman, London.

Dickens, B., and Brown, W.E., 1970. The crystal structure of calcium carbonate hexahydrate at $120^{\circ} \mathrm{C}$. Inorganic Chemistry. 9 (3): 480-486. doi:10.1021/ic50085a010.

Dieckmann, G. S., Nehrke, G., Papadimitriou, S., Göttlicher, J., Steininger, R., Kennedy, H., WolfGladrow, D., Thomas, D. N. (2008). Calcium carbonate as ikaite crystals in Antarctic sea ice. Geophysical Research Letters, 35(8). doi:10.1029/2008gl033540

Dieckmann, G. S., Nehrke, G., Uhlig, C., Göttlicher, J., Gerland, S., Granskog, M. A., \& Thomas, D. N. (2010). Brief Communication: Ikaite $\left(\mathrm{CaCO}_{3} \cdot 6 \mathrm{H}_{2} \mathrm{O}\right)$ discovered in Arctic sea ice. The Cryosphere, 4(2), 227-230. doi:10.5194/tc-4-227-2010

Emeleus, C.H. (1964) The Grønnedal-Ika alkaline complex, South Greenland: Copenhagen. Meddelelser om Grønland 186, 75 p. 
Geilfus, N. X., Carnat, G., Dieckmann, G. S., Halden, N., Nehrke, G., Papakyriakou, T., . . . Delille, B. 2013. First estimates of the contribution of $\mathrm{CaCO} 3$ precipitation to the release of $\mathrm{CO} 2$ to the atmosphere during young sea ice growth. Journal of Geophysical Research: Oceans, 118(1), 244-255. doi:10.1029/2012JC007980

Hansen, M.O., Buchardt, B., Kuhl, M., and Elberling, B., 2011, The Fate of the Submarine Ikaite Tufa Columns in Southwest Greenland Under Changing Climate Conditions. Journal of Sedimentary Research, v. 81, p. 553-561. doi:10.2110/jsr.2011.50.

Hardie, L. A. (1996). Secular variation in seawater chemistry: An explanation for the coupled secular variation in the mineralogies of marine limestones and potash evaporites over the past 600 my. Geology, 24(3), 279-283.

Huggett, J.M., Schultz, B.P., Shearman D.J, and Smith A.J, 2005, The petrology of ikaite pseudomorphs and their diagenesis. Proceedings of the Geologists' Association, v.116, Issues 3-4, p. 207-220.

Hu, Y.B., Wolf-Gladrow, D.A., Dieckmann, G.S., Völker, C., \& Nehrke, G. (2014a). A laboratory study of ikaite (CaCO 3. $6 \mathrm{H} 2 \mathrm{O}$ ) precipitation as a function of $\mathrm{pH}$, salinity, temperature and phosphate concentration. Marine Chemistry, 162, 10-18.

Johnston, J., Merwin, H.E., and Williamson, E.D., 1916, The Several Forms of Calcium Carbonate. American Journal of Science, fourth series 41, 246, p. 473-493.

Lasaga, A. C. (2014). Kinetic theory in the earth sciences. Princeton University Press.

Lin, Y. P., \& Singer, P. C. (2006). Inhibition of calcite precipitation by orthophosphate: speciation and thermodynamic considerations. Geochimica et Cosmochimica Acta, 70(10), 2530-2539.

Lowenstein, T. K., Timofeeff, M. N., Brennan, S. T., Hardie, L. A., \& Demicco, R. V. (2001). Oscillations in Phanerozoic seawater chemistry: Evidence from fluid inclusions. Science, 294(5544), 1086-1088.

Marland, G., 1975, The stability of $\mathrm{CaCO}_{3} \cdot \mathrm{H}_{2} \mathrm{O}$ (ikaite). Geochimica et Cosmochimica Acta, v. 39, p. 83-91.

Morales, C., Rogov, M., Wierzbowski, H., Ershova, V., Suan, G., Adatte, T., Föllmi, K., Tegelaar, E., Reichart, G. and Middelburg, J. J., 2017, Glendonites track methane seepage in Mesozoic polar seas. Geology, G38967-1.

Mucci, A., Canuel, R., and Zhong, S., 1989, The solubility of calcite and aragonite in sulfate-free seawater and the seeded growth kinetics and composition of the precipitates at $25^{\circ} \mathrm{C}$. Chemical Geology, v. 74, p. 309-320.

Nielsen, M.R., Sand, K.K., Rodriguez-Blanco, J.D., Bovet, N., Generosi, J., Dalby, K.N., and Stipp, S.L.S., 2016, Inhibition of Calcite Growth: Combined Effects of $\mathrm{Mg}^{2+}$ and $\mathrm{SO}_{4}{ }^{2-}$. Crystal Growth \& Design, v. 16, p. 6199-6207, doi:10.1021/acs.cgd.6b00536. 
Nishiyama, R., Munemoto, T., \& Fukushi, K. (2013). Formation condition of monohydrocalcite from CaCl2-MgCl2-Na2CO3 solutions. Geochimica et Cosmochimica Acta, 100, 217-231. doi:10.1016/j.gca.2012.09.002

Ohmura, A., and Reeh, N., 1991, New precipitation and accumulation maps for Greenland. Journal of Glaciology, v. 37, no. 125.

Parkhurst, D.L., and Appelo, C.A.J., 2013, Description of input and examples for PHREEQC version 3-A computer program for speciation, batch-reaction, one-dimensional transport, and inverse geochemical calculations: U.S. Geological Survey Techniques and Methods, book 6, chap. A43, 497 p., available only at https://pubs.usgs.gov/tm/06/a43/.

Pauly, H., 1963, “Ikaite”, A New Mineral from Greenland. Arctic v. 16, p. 263-264.

Pelouze, J., 1831, Sur la production artificielle du carbonate de chaux cristallise, et sur deux combinaisons de ce sel avec l'eau. Annales de Chimie et de Physique, ser. 2, v. 48, p. 301-307.

Rink, H.J., 1866, Eskimoiske Eventyr og Sagn. København, C.A. Reitzel.

Rodriguez-Blanco, J.D., Shaw, S., Bots, P., Roncal-Herrero, T., and Benning, L.G., 2014, The role of Mg in the crystallization of monohydrocalcite. Geochimica et Cosmochimica Acta, v. 127, p. 204-220.

Rodriguez-Ruiz, I., Veesler, S., Gómez-Morales, J., Delgado-López, J.-M., Grauby, O., Hammadi, Z., Candoni, N. and García-Ruiz, J.M., 2014, Transient Calcium Carbonate Hexahydrate (Ikaite) Nucleated and Stabilized in Confined Nano- and Picovolumes. Crystal Growth, v. 14, p. $792-802$.

Schubert, C.J., Nürnberg, D., Scheele, N., Pauer, F., Kriews, M., 1997. ${ }^{13} \mathrm{C}$ isotope depletion in ikaite crystals: evidence for methane release from the Siberian shelves? Geo-Marine Letters 17, 169-174.

Stanley, S. M., \& Hardie, L. A. (1999). Hypercalcification: paleontology links plate tectonics and geochemistry to sedimentology. GSA Today, 9(2), 1-7.

Stockmann, G.J., Tollefsen, E., Balic-Zunic, T., Langhof, J. and Skogby, H., 2016, Synthetic ikaite precipitation simulating conditions in Ikka Fjord, SW Greenland. Abstract, 32nd Nordic Geological Winter Meeting, Helsinki, Finland.

Stumm, W., and Morgan, J.J., 1996, Aquatic Chemistry. Chemical Equilibria and Rates in Natural Waters. Third Edition. John Wiley \& Sons, Inc., New York, 1022 pp.

Suess, E., Balzer, W., Hesse, K. F., Muller, P. J., Ungerer, C. A., \& Wefer, G. 1982. Calcium carbonate hexahydrate from organic-rich sediments of the antarctic shelf: precursors of glendonites. Science, 216(4550), 1128-1131. doi:10.1126/science.216.4550.1128

Teichert, B. M. A., \& Luppold, F. W. (2013). Glendonites from an Early Jurassic methane seep Climate or methane indicators? Palaeogeography, Palaeoclimatology, Palaeoecology, 390, 81-93. doi:10.1016/j.palaeo.2013.03.001 
Trampe, E. C., Larsen, J. E., Glaring, M. A., Stougaard, P., \& Kühl, M., 2016. In situ Dynamics of O2, pH, Light, and Photosynthesis in Ikaite Tufa Columns (Ikka Fjord, Greenland)—A Unique Microbial Habitat. Frontiers in microbiology, 7.

Upton, B. G. J., Emeleus, C. H., Heaman, L. M., Goodenough, K. M., \& Finch, A. A. (2003). Magmatism of the mid-Proterozoic Gardar Province, South Greenland: chronology, petrogenesis and geological setting. Lithos, 68(1-2), 43-65. doi:10.1016/S00244937(03)00030-6

Veizer, J. (1992). Depositional and diagenetic history of limestones: stable and radiogenic isotopes. In Isotopic signatures and sedimentary records (pp. 13-48). Springer Berlin Heidelber. 


Manuscript 



\section{Chemical controls on ikaite formation}

\section{Elin Tollefsen ${ }^{1}$, Gabrielle Stockmann ${ }^{1}$, Alasdair Skelton ${ }^{1}$, Carl-Magnus Mörth ${ }^{1}$, Christophe Dupraz $^{1}$ and Erik Sturkell ${ }^{2}$}

${ }^{1}$ Department of Geological Sciences, Stockholm University, 10691 Stockholm, Sweden (elin.tollefsen@geo.su.se)

${ }^{2}$ Department of Earth Sciences, University of Gothenburg, 40530 Gothenburg, Sweden

\section{ABSTRACT}

Ikaite $\left(\mathrm{CaCO}_{3} \cdot 6 \mathrm{H}_{2} \mathrm{O}\right)$ is a carbonate mineral which despite its metastable nature has been found in sediments, tufa columns and sea-ice. The mineral ikaite is used as a proxy in paleoclimatology and could potentially be used for carbon sequestration. Under favourable conditions such as at the type locality Ikka Fjord in southwest Greenland, ikaite forms tufa columns which can grow up to $0.5 \mathrm{~m} /$ year. The reason why ikaite forms at this site remains unknown, however the cold temperature $\left(<6^{\circ} \mathrm{C}\right)$ in the fjord and $\mathrm{Mg}^{2+}$ and $\mathrm{SO}_{4}{ }^{2-}$ in the seawater are possible factors promoting ikaite formation. Here we show that the formation of the unique tufa columns in Ikka Fjord is controlled by the Mg concentration in seawater and the $\mathrm{pH}$ of the spring water. This was done by conducting a series of laboratory experiments to test the effect of $\mathrm{Mg}^{2+}$ and $\mathrm{SO}_{4}{ }^{2-}$ in seawater and the $\mathrm{pH}$ of the spring water on ikaite precipitation. We found that ikaite precipitated when both seawater and synthetic seawater from which $\mathrm{SO}_{4}{ }^{2-}$ had been removed were used in the experiments. However, ikaite did not precipitate in experiments conducted with synthetic seawater from which $\mathrm{Mg}$ had been removed. In these experiments, calcite precipitated instead of ikaite. By varying the $\mathrm{Mg}$ content of synthetic seawater and the $\mathrm{pH}$ of the spring water, we constructed a kinetic stability diagram for ikaite and calcite as a function of $\mathrm{Mg}^{2+}$ concentration and $\mathrm{pH}$. One possible explanation of our finding is that $\mathrm{Mg}^{2+}$ inhibits calcite nucleation and thereby allows metastable ikaite to form instead. 


\section{INTRODUCTION}

Ikaite $\left(\mathrm{CaCO}_{3} \cdot 6 \mathrm{H}_{2} \mathrm{O}\right)$ is a metastable mineral, which was first synthesized experimentally in the early 1800s (Pelouze 1831) and later discovered in nature in the Ikka fjord, southwest Greenland (Pauly 1963). Ikka fjord lies at the base of an alkaline magmatic complex and in the cold water of the fjord, ikaite forms up to $20 \mathrm{~m}$ high columns (Fig. 1A) which can grow up to $0.5 \mathrm{~m}$ per year (Hansen et al. 2011). The pressure-temperature stability of ikaite was constrained by Marland (1975) in the system $\mathrm{CaCO}_{3}-\mathrm{H}_{2} \mathrm{O}$. The stability field (cold temperature and relatively high pressure) for ikaite does not exist on Earth (Fig. 1B), but nevertheless ikaite has been found in sediments, in sea ice and in the form of tufa columns. It is therefore likely that parameters other than pressure and temperature favour formation of metastable ikaite instead of the stable carbonate phase, calcite.

In nature, ikaite has been observed at temperatures between $-2^{\circ} \mathrm{C}$ and $7^{\circ} \mathrm{C}$ (Huggett et al. 2005). Ikaite remains relatively stable at near-freezing temperatures but decomposes quickly to calcite and water at higher temperatures (Johnston et al. 1916). In Ikka Fjord, ikaite precipitates from a mixture of seawater and spring water which seeps up from the bottom of the fjord. The spring water (hereafter referred to as Ikka water) is a sodium carbonate rich solution with $\mathrm{pH} 10.16$ to 10.5 (at $3.6 \pm 0.5^{\circ} \mathrm{C}$ ) and with relatively high concentration (9-25 ppm) of $\mathrm{PO}_{4}{ }^{3-}$ (Buchardt et al. 2001). The composition of the Ikka water reflects water-rock interaction in the Grønnedal-Íka igneous complex which comprises carbonatite and alkaline rocks, mainly nepheline syenite (Emeleus 1964). This igneous complex forms the high ground on the northern side and underlies part of the fjord. Meteoric water precipitating on this complex percolates along fractures in the rocks and reacts with its constituent minerals. The nepheline syenites are rich in nepheline $\left(\mathrm{Na}_{3} \mathrm{~K}\left(\mathrm{Al}_{14} \mathrm{Si}_{4} \mathrm{O}_{16}\right)\right)$, and the carbonatite in calcite $\left(\mathrm{CaCO}_{3}\right)$ and a smaller amount of 
siderite $\left(\mathrm{FeCO}_{3}\right)$ and apatite $\left(\mathrm{Ca}_{5}\left(\mathrm{PO}_{4}\right)_{3}(\mathrm{~F}, \mathrm{Cl}, \mathrm{OH})\right)$. It is likely that reactions involving these minerals lead to high concentrations of $\mathrm{Na}^{+}, \mathrm{CO}_{3}{ }^{2-}$ and $\mathrm{PO}_{4}{ }^{3-}$ in the Ikka water.

Buchardt et al. (2001) suggested that the precipitation of ikaite in the fjord was favoured by the cold temperature $\left(<6^{\circ} \mathrm{C}\right)$ and the presence of $\mathrm{PO}_{4}{ }^{3-}$ in the Ikka water which is known to inhibit the precipitation of calcite (Burton et al. 1986). Stockmann et al. (2016) experimentally tested the effect of $\mathrm{PO}_{4}{ }^{3-}$ on synthetic ikaite precipitation. In their study, synthetic ikaite was found to precipitate both with and without $\mathrm{PO}_{4}{ }^{3-}$ in solution. They therefore suggested that $\mathrm{Mg}^{2+}$ and/or $\mathrm{SO}_{4}{ }^{2-}$ in the seawater might control ikaite formation because both of these elements are known to inhibit calcite precipitation (Mucci et al. 1989, Nielsen et al. 2016). Further, Nielsen et al. (2016) showed that $\mathrm{MgSO}_{4}{ }^{0}$ was a particularly effective inhibitor of calcite growth. In our study, we investigated how $\mathrm{Mg}^{2+}$ and $\mathrm{SO}_{4}{ }^{2-}$ as well as $\mathrm{pH}$ control ikaite precipitation by conducting a series of experiments in which we mixed synthetic Ikka water with natural and synthetic seawater in equal proportions. Firstly, we determined which of $\mathrm{Mg}^{2+}$ and $\mathrm{SO}_{4}{ }^{2-}$ affects ikaite precipitation by removing one and then the other of these ions from the synthetic waters used in the first experiments. Secondly, we varied the concentration of the ion which affected ikaite precipitation. Ikka water was simulated by a mixture of $0.1 \mathrm{M}$ of $\mathrm{Na}_{2} \mathrm{CO}_{3}$ and $0.1 \mathrm{M}$ of $\mathrm{NaHCO}_{3}$. Different mixing ratios were used to find out how $\mathrm{pH}$ affects ikaite precipitation. In nature, the formation of ikaite is associated with alkaline waters and relatively high $\mathrm{pH}$ environments (Council and Bennett 1993, Bischoff et al. 1993b, Omelon et al. 2001, Buchardt et al. 2001). We therefore conducted our experiments at relatively high $\mathrm{pH}$ values $\left(8.3-11.8\right.$ at $\left.5^{\circ} \mathrm{C}\right)$.

\section{IKKA FJORD}

The age of the columns in Ikka Fjord is unknown but their formation must post date the most recent period of glaciation during which the fjord was ice-filled. In 1963 Pauly identified the mineral that makes the columns as the calcium carbonate hexahydrate found 
in experiments conducted by Johnston et al. (1916), and named the mineral ikaite after the fjord.

The climate in the area is low arctic with mean annual temperature between $-1.9^{\circ} \mathrm{C}$ and $+2.9^{\circ} \mathrm{C}$ and annual precipitation of $\sim 1000 \mathrm{~mm}$ (Hansen et al. 2011, Ohmura and Reeh 1991). Ice and snow generally cover Ikka Fjord from November to May (Buchardt et al. 2001). The fjord is a $13 \mathrm{~km}$ long narrow glacial valley. The upper part of the fjord is comparatively shallow $(<25 \mathrm{~m})$. Here, over 700 columns are found, covering an area of 3 x $0.5 \mathrm{~km}$ (Buchardt et al. 1997). This part of the fjord is flanked by steep-sided up to $500 \mathrm{~m}$ high mountains. The bedrock that forms the mountains flanking the northern side of the fjord consists of carbonatites and nepheline syenites of the Grønnedal-Íka complex (Emeleus 1964). They belong to a suite of rocks, which was formed during continental rifting 1.3 billion years ago in a time referred to as the Gardar episode (Upton and Blundell 1978).

The ikaite columns form when Ikka water seeps up from the bottom of the fjord and mixes with seawater. Buchardt et al. (2001) used $\delta^{13} \mathrm{C}, \delta{ }^{18} \mathrm{O}$ and ${ }^{87} \mathrm{Sr} /{ }^{86} \mathrm{Sr}$ values of the ikaite crystal to determine the origins of $\mathrm{CO}_{3}{ }^{2-}$ and $\mathrm{Ca}^{2+}$, which they found to be Ikka water and seawater, respectively. The columns and their formation were monitored during several seasons from 1995 to 2013 by a Danish-British research team (Buchardt et al. 2001, Hansen et al. 2011, Trampe et al. 2016). This team found that seawater in the fjord is stratified and that the upper two meters are nearly fresh due to water coming in from small streams. Below the halocline layer $(\sim 4 \mathrm{~m})$, water temperature remains below $6^{\circ} \mathrm{C}$ and salinity is $32.2 \%$ all year round (Hansen et al. 2011). The low temperature is maintained by inflow of water from the East Greenland Current into the fjord (Buchardt et al. 2001). The composition of Ikka water emanating from the columns was investigated by Buchardt et al. (2001) and is shown in Table 1. 
Dahl and Buchardt (2006) investigated the mineralogy of the fresh columns as well as debris from the columns found at the bottom of the fjord. The fresh columns are mostly composed of white ikaite crystals with minor aragonite, monohydrocalcite (MHC) and calcite, whereas debris from the columns was calcite, MHC and an unidentified magnesium carbonate (Dahl and Buchardt 2006).

\section{METHODS}

A series of experiments were set up at the Department of Geological Sciences, Stockholm University to simulate the conditions at which ikaite forms in Ikka Fjord. In our experiments, synthetic Ikka water and either natural or synthetic seawater were mixed. Julabo F-32 and F-25 cooling baths were used to maintain the temperature at $5.00 \pm 0.03^{\circ} \mathrm{C}$ during the experiments. The rate of mixing of Ikka water in seawater was controlled using an Ismatec BVK peristaltic pump. In the experiments we used natural seawater collected near Andøya, Norway which was filtered with Munktelle 00M filters and synthetic seawater prepared to replicate the average seawater composition reported by Stumm and Morgan (1996). The seawater from Andøya was considered a good analogue of seawater in Ikka Fjord for the purpose of our study, because of its similar salinity (33.1\%o respectively 32.2\%o) and because $\mathrm{PO}_{4}$ concentrations were below detection limits. The composition of synthetic seawater, which was prepared by mixing powders from MERCK in 1 litre of ultrapure deionized water (MilliQ resistivity $>18.2 \mathrm{M} \Omega \cdot \mathrm{cm}$ ), is shown in Table 1.

In our experiments, we mixed the following solutions:

- Solution 1 represented Ikka water. It was made with a mixture of $0.1 \mathrm{M} \mathrm{Na}_{2} \mathrm{CO}_{3}$ and $0.1 \mathrm{M} \mathrm{NaHCO}_{3}$ in ratios 1:1, 3:1 and 4:1 which represent the range of different Ikka waters in the columns described by Buchardt et al. (2001). The pH of these solutions were $10.1,10.6$ and 10.7 respectively at $5^{\circ} \mathrm{C}$. We omitted the other elements detected in the Ikka water because of their low concentrations. Stockmann et al. (2016) showed that $\mathrm{PO}_{4}$ did not affect ikaite precipitation in 
simulated Ikka Fjord conditions and therefore we also excluded $\mathrm{PO}_{4}$ from the synthetic Ikka waters. We extended the range of $\mathrm{pH}$ values beyond those seen at Ikka Fjord by varying the ratios of $0.1 \mathrm{M} \mathrm{Na}_{2} \mathrm{CO}_{3}$ and $0.1 \mathrm{M} \mathrm{NaHCO}$ from $1: 15$ to 1:0.

- Solution 2 represented seawater. We used natural seawater from Andøya, Norway and synthetic seawater (Table 1). In some experiments, either $\mathrm{SO}_{4}{ }^{2-}$ or $\mathrm{Mg}^{2+}$ was removed. In other experiments, $\mathrm{Mg}^{2+}$ concentration was varied by varying the proportions of $\mathrm{MgCl}_{2} \cdot 6 \mathrm{H}_{2} \mathrm{O}$ in the mixture. In some experiments, loss in ionic strength due to removal of $\mathrm{Mg}$ was compensated for by addition of $\mathrm{NaCl}$. This was done because variation in ionic strength can interfere with calcite precipitation and/or ikaite precipitation (Hu et al. 2014).

The experiment was set up by placing one flask with synthetic Ikka water (solution 1) and a second flask with seawater (solution 2) in the first cooling bath maintained at $5^{\circ} \mathrm{C}$. Each flask was connected with $1.52 \mathrm{~mm}$ Tygon tubing to the peristaltic pump and further to the mixing beaker which was placed in the second cooling bath (Fig. 2). The two solutions were pumped at a rate of $0.48 \pm 0.06 \mathrm{ml} / \mathrm{min}$ into the mixing beaker until $\sim 300 \mathrm{ml}$ of mixed solution was obtained, at which point the experiment was stopped. The $\mathrm{pH}$ of each solution was measured using a HANNA HI-9126 pH meter a HI-1230B electrode and the temperature was measured with a HI-7662 sensor after each experiment. The mixed solution was put into a $5^{\circ} \mathrm{C}$ cold room where it was filtered with Munktell 00K filters. The precipitate in the filter was dried overnight and collected the next day from the filter paper, weighed, and thereafter stored in a freezer $\left(-18^{\circ} \mathrm{C}\right)$. Seeding from calcite leftover from previous experiments was at one point detected. The affected experiments were re-run and thereafter, the beakers were cleaned with weak acid between experiments. Finally, replicate runs of four experiments (1, 2, 4 and 6) gave the same results. 
The minerals from the precipitate were identified by X-ray Powder Diffraction (XRD) analysis with an X Pert Pro instrument from PANalytical and the program Data Colllector at the Swedish Museum of Natural History in Stockholm. The sample supporter was put into a freezer $\left(-18^{\circ} \mathrm{C}\right)$ for 10 min before analysis so as to preserve the ikaite crystals. The measurement program used was Absolute Scan 5-70 ${ }^{\circ}$ with a runtime of 11 min. Mineral identification and quantification (Rietveld refinement) of the phases was done with the program HighScore Plus.

We took SEM images of samples from some experiments with a Carl Zeiss Merlin Field-Emission Scanning Electron Microscope (FESEM) using Quorum Technologies PP3000T Cryo Preparation System at Umeå University and with an Environmental Scanning Electron Microscope with Field Emission Gun of the brand Philips XL-30ESEM-FEG at Stockholm University.

The conductivity, salinity and the ion concentrations of the natural seawater from Andøya, Norway were measured at Stockholm University. The anions were measured with an IC20 Ion Chromatograph from Dionex and the cations with an ICP-AES Inductively coupled plasma - atomic emission spectroscopy with autosampler SPS-5 from Varian.

We used the software PhreeqC Interactive version 3.3.0 (Parkhurst and Appelo, 2013) for geochemical modelling of the experiments to 1) determine the saturation index (SI) of the minerals found in Ikka Fjord and the experiments, and 2) obtain expected $\mathrm{pH}$, ionic strength, alkalinity and ionic compositions of the solutions.

\section{RESULTS}

The first series of experiments were designed to find out if either $\mathrm{Mg}^{2+}$ or $\mathrm{SO}_{4}{ }^{2-}$ controlled ikaite precipitation by excluding them from the synthetic seawater mixture. In these experiments (Table 2 and TableA1), ikaite precipitated when we used natural seawater (exp. 1), synthetic seawater (exp. 2) and synthetic seawater with $\mathrm{SO}_{4}{ }^{2-}$ removed (exp. 3), whereas calcite precipitated when we used synthetic seawater with $\mathrm{Mg}^{2+}$ removed (exp. 4) 
and synthetic seawater with $\mathrm{Mg}^{2+}$ removed and $\mathrm{NaCl}$ added to maintain ionic strength (exp. 5).

The second, third and fourth series of experiments were designed to find threshold concentrations of $\mathrm{Mg}^{2+}$ required for ikaite precipitation to occur at different $\mathrm{pH}$ values. In these experiments, $\mathrm{Mg}^{2+}$ concentration was increased stepwise (Table 2 and Table A1). The threshold $\mathrm{Mg}^{2+}$ concentrations were 2.46-4.92 ( \pm 0.02$)$, 4.92-7.38 $( \pm 0.02)$ and 7.38$9.84( \pm 0.02) \mathrm{mmol} / \mathrm{kg}$ for the second third and fourth series, respectively (Table 2 and Table A1). Ikaite precipitated at $\mathrm{Mg}^{2+}$ concentrations higher than these threshold values either alone (exp. 8, 9, 12b, 20 and 25: Fig. 3A), with calcite (exp. 7, 17a, 17b, 18 and 19: Fig. 3B) or with traces of nesquehonite (exp. 13). Calcite precipitated at lower $\mathrm{Mg}^{2+}$ concentrations, either alone (exp. 10, 14, 15, 21, 22 and 24; Fig. 3E and F), with aragonite (exp. 11 and 23) or with traces of monohydrocalcite (exp. 16). Both ikaite and either calcite or aragonite precipitated in 2 experiments run at the threshold $\mathrm{Mg}^{2+}$ concentration (exp. 6a and 6b: Fig. 3C).

The fifth and sixth series of experiments were designed to find threshold $\mathrm{pH}$ values required for ikaite precipitation to occur at different concentrations of $\mathrm{Mg}^{2+}$. In the fifth series, Andøya seawater (Table 1) was used. This gave a $\mathrm{Mg}^{2+}$ concentration of 22.80 $\pm 0.50 \mathrm{mmol} / \mathrm{kg}$ in the mixed solution. In the sixth series, synthetic seawater was used and the $\mathrm{Mg}^{2+}$ concentration of the mixed solution was $14.76 \pm 0.02 \mathrm{mmol} / \mathrm{kg}$. In both series, $\mathrm{pH}$ was increased stepwise by increasing the proportion of $0.1 \mathrm{M} \mathrm{Na}_{2} \mathrm{CO}_{3}$ in solution 1 . The threshold $\mathrm{pH}$ values at and above which ikaite was precipitated were 9.32 and 9.69. Calcite precipitated below this threshold either alone (exp. 34) or with aragonite (exp. 27, 28 and 35: Fig. 3D). In one experiment conducted using Andøya seawater at comparatively low pH (8.62), no precipitate was formed. Ikaite precipitated above this threshold either alone (exp. 30, 31 and 32), with calcite (exp. 36 and 37) or with an amorphous phase (exp. 33). 
Monohydrocalcite precipitated together with both calcite and ikaite in an experiment run at the threshold $\mathrm{pH}$ value (exp. 29).

By combining our results, we were able to construct a kinetic stability diagram for ikaite precipitation as a function of $\mathrm{pH}$ and $\mathrm{Mg}^{2+}$ concentration at $5^{\circ} \mathrm{C}$ (Fig. 4). The $\mathrm{pH}$ was calculated using PhreeqC because the measured $\mathrm{pH}$ from the experiments was not representative due to rapid precipitation in the supersaturated mixed solution, which lowered its value rapidly. Ikaite was found to precipitate at high $\mathrm{Mg}^{2+}$ concentration and high $\mathrm{pH}$ (Fig. 4), i.e. the threshold $\mathrm{Mg}^{2+}$ concentration required for ikaite precipitation to occur is lower at higher $\mathrm{pH}$. Our results also suggest monohydrocalcite precipitation at lower $\mathrm{pH}$ and higher (seawater) $\mathrm{Mg}^{2+}$ concentration. The line which bounds the field within which ikaite precipitation occurs follows a power law:

$$
\mathrm{C}_{\mathrm{Mg}}=\left(2.68 \times 10^{15}\right) \mathrm{pH}^{-14.49}
$$

where $\mathrm{C}$ is concentration of $\mathrm{Mg}^{2+}$ in $\mathrm{mmol} / \mathrm{kg}$.

\section{DISCUSSION}

In our experiments removing $\mathrm{SO}_{4}{ }^{2-}$ from the seawater had no effect on ikaite precipitation (Table 2; exp. 3). On the other hand, our experimental results show that both $\mathrm{Mg}^{2+}$ concentration in seawater and $\mathrm{pH}$ control ikaite precipitation (Table 2; Table A1; Fig. 4). Ikaite precipitated in solutions with higher $\mathrm{pH}$ values and $\mathrm{Mg}^{2+}$ concentrations. In seawater, $\left(\mathrm{Mg}^{2+}\right.$ concentration of mixed solution $\left.=22.80 \pm 0.50 \mathrm{mmol} / \mathrm{kg}\right)$, ikaite precipitation required $\mathrm{pH}>9.3$ (Table 2; exp. 29).

Geochemical modelling using PhreeqC verified that in most cases, phases which precipitated in our experiments were supersaturated implying that the phase which actually precipitates reflects kinetic factors (Table A2). Exceptions are (1) nesquehonite, which although undersaturated, precipitated in exp. 13, possibly because nesquehonite is not well constrained in PhreeqC, and (2) magnesite and hydromagnesite, which were supersaturated in experiments with natural seawater and synthetic seawater containing $\geq 0.5 \mathrm{~g}$ 
$\mathrm{MgCl}_{2} \cdot 6 \mathrm{H}_{2} \mathrm{O}$, representing $\geq 1.23 \mathrm{mM}$ of $\mathrm{Mg}^{2+}$ in mixed solution. These exceptions also point to kinetic factors as a primary control on which phase precipitates.

Several findings from our study suggest that a primary kinetic factor which allows ikaite precipitation is that $\mathrm{Mg}^{2+}$ inhibits calcite nucleation and/or growth. These are:

- $\quad$ Scanning Electron Microscope images reveal a progression from euhedral ikaite crystals precipitated from solutions with high $\mathrm{pH}$ and high $\mathrm{Mg}^{2+}$ concentration (Fig. 3A-B) to calcite crystals with spherulite morphology (3D), smooth rhomb structures (3E) and ultimately euhedral forms (Fig. 3F) precipitated from a solution that did not contain any $\mathrm{Mg}^{2+}$.

- The amount of precipitates obtained was generally higher for ikaite (>0.08 g) and lower for calcite and aragonite ( $<0.08 \mathrm{~g})$. This could imply that ikaite nucleation and growth is kinetically favoured but might also reflect the higher molecular weight of ikaite because of its water content.

- $\quad$ Calcite nucleation was triggered by seeding in two experiments (12a and 19a).

- $\quad$ Calcite often precipitates together with aragonite which is known to precipitate when calcite nucleation is inhibited by the presence of $\mathrm{Mg}^{2+}$ (Deleuze et al. 1997). Magnesium inhibiting calcite nucleation has been described previously (Mucci et al. 1988, Deleuze et al. 1997 and Nielsen et al. 2016). Nielsen et al. (2016) showed experimentally that $\mathrm{SO}_{4}{ }^{2-}, \mathrm{Mg}^{2+}$ and $\mathrm{MgSO}_{4}{ }^{0}$ inhibit calcite growth. The inhibiting effect of $\mathrm{SO}_{4}{ }^{2-}$ and $\mathrm{MgSO}_{4}{ }^{0}$ on calcite cannot explain ikaite precipitation in our study, because ikaite precipitation occurred even after removal of $\mathrm{SO}_{4}{ }^{2-}$ from the synthetic seawater mixture. Geochemical modelling using PhreeqC showed that $\mathrm{Mg}^{2+}$ cations preferentially form $\mathrm{MgCO}_{3}{ }^{0}$ rather than $\mathrm{MgSO}_{4}{ }^{0}$ in our experiments, predicting $11.45 \mathrm{mmol} / \mathrm{kg}$ of $\mathrm{MgCO}_{3}{ }^{0}$ and $1.0 \mathrm{mmol} / \mathrm{kg}$ of $\mathrm{MgSO}_{4}{ }^{0}$ in natural seawater (Table A3). Also, the experimental 
threshold for ikaite precipitation occurs after the concentration of both $\mathrm{Mg}^{2+}$ and $\mathrm{MgCO}_{3}{ }^{0}$ has exceeded the concentration of $\mathrm{Ca}^{2+}$ (Fig. A1).

It has been shown that when calcite and monohydrocalcite (MHC) precipitate from highly supersaturated solutions, the first phase to nucleate is metastable amorphous calcium carbonate (ACC) which is transformed to vaterite and then to the more stable phase calcite (Bots et al. 2012). If the solution has high $\mathrm{Mg} / \mathrm{Mg}+\mathrm{Ca}$ ratio the ACC will be transformed to MHC (Rodriguez-Blanco et al. 2013). We only detected an amorphous phase in one of our experiments (exp. 33) but this might be because the XRD analyses were not done immediately after precipitation. However, in a recent experimental study (Rodriguez-Ruiz et al. 2014), calcium carbonate was precipitated in Confined Nano- and Picovolumes at $20^{\circ} \mathrm{C}$ and the first phase to crystallize was ikaite and no ACC was detected. This could mean that ikaite preferentially crystallizes directly from a supersaturated solution. This is consistent with the results of our study.

Our finding, that $\mathrm{pH}$ controls ikaite precipitation, is consistent with previous experimental work by $\mathrm{Hu}$ et al. (2014). These authors investigated controlling factors of ikaite precipitation in sea ice and found $\mathrm{pH}$ to be the controlling factor. However, they did not test the effect of $\mathrm{Mg}^{2+}$ in their study.

\section{CONCLUSIONS}

We conclude that ikaite precipitation in Ikka Fjord and potentially elsewhere is controlled by the $\mathrm{Mg}^{2+}$ concentration in seawater and $\mathrm{pH}$ of the (Ikka) water. Ikaite precipitation is favoured by high $\mathrm{pH}$ and $\mathrm{Mg}^{2+}$ concentration, with ikaite precipitation in natural seawater requiring a $\mathrm{pH}>9$.3. We further conclude that one reason for ikaite precipitation to occur is that $\mathrm{Mg}^{2+}$ inhibits calcite precipitation. Our contribution towards the understanding of the chemical controls on ikaite formation has implications for carbon sequestration given the rapidity at which ikaite can form. 


\section{ACKNOWLEDGMENTS}

We thank M. Ahlbom, V. Brüchert, J. Ek, P. Hjelmqvist, J. Langhof, C.C.N. Lee, J. Rattray, H. Skogby, M. Söderman and J. West for assistance in lab and the Bolin Centre for financial support.

\section{REFRENCES}

Bischoff, J. L., Stine, S., Rosenbauer, R. J., Fitzpatrick, J. A., \& Stafford Jr., T. W. 1993b: Ikaite precipitation by mixing of shoreline springs and lake water, Mono Lake, California, USA. Geochimica et Cosmochimica Acta 57, 3855-3865.

Bots, P., Benning, L.G., Rodriguez-Blanco, J.D., Roncal-Herrero, T., and Shaw, S., 2012, Mechanistic insights into the crystallization of amorphous calcium carbonate (ACC). Crystal Growth \& Design, v. 12, p. 3806-3814, doi: 10.1021/CG300676b.

Buchardt, B., Israelson, C., Seaman, P., and Stockmann, G., 2001, Ikaite tufa in Ikka Fjord, southwest Greenland: Their formation by mixing of seawater and alkaline spring water. Journal of Sedimentary Research, v. 71, p. 176-189.

Burton, E.S., and Walter, L.M. 1986, The effect of orthophosphate on carbonate mineral dissolution rates in seawater. Chemical Geology, v. 56, p. 313-323.

Council, T.C., and Bennett, P.C., 1993, Geochemistry of ikaite formation at Mono Lake, California: implications for the origin of tufa mounds, Geology, v. 21, p. 971-974.

Dahl, K., and Buchardt, B., 2006, Monohydrocalcite in the Arctic Ikka Fjord, SW Greenland: First Reported Marine Occurrence. Journal of Sedimentary Research v. 76, p. $460-471$.

Deleuze, M., and Brantley, S., 1997, Inhibition of calcite crystal growth by $\mathrm{Mg}^{2+}$ at $100^{\circ} \mathrm{C}$ and 100 bars: Influence of growth regime. Geochim. Cosmochim. Acta 7, p. 14751485.

Emeleus, C.H. (1964) The Grønnedal-Ika alkaline complex, South Greenland: Copenhagen. Meddelelser om Grønland 186, 75 p. 
Johnston, J., Merwin, H.E., and Williamson, E.D., 1916, The Several Forms of Calcium Carbonate. American Journal of Science, fourth series 41, 246, p. 473-493.

Hansen, M.O., Buchardt, B., Kuhl, M., and Elberling, B., 2011, The Fate of the Submarine Ikaite Tufa Columns in Southwest Greenland Under Changing Climate Conditions. Journal of Sedimentary Research, v. 81, p. 553-561. doi:10.2110/jsr.2011.50.

Huggett, J.M., Schultz, B.P., Shearman D.J, and Smith A.J, 2005, The petrology of ikaite pseudomorphs and their diagenesis. Proceedings of the Geologists' Association, v.116, Issues 3-4, p. 207-220.

Hu, Y. B., Wolf-Gladrow, D. A., Dieckmann, G. S., Völker, C., \& Nehrke, G. (2014a). A laboratory study of ikaite ( $\mathrm{CaCO} 3 \cdot 6 \mathrm{H} 2 \mathrm{O})$ precipitation as a function of $\mathrm{pH}$, salinity, temperature and phosphate concentration. Marine Chemistry, 162, 10-18.

Marland, G., 1975, The stability of $\mathrm{CaCO}_{3} \cdot \mathrm{H}_{2} \mathrm{O}$ (ikaite). Geochimica et Cosmochimica Acta, v. 39, p. 83-91.

Mucci, A., Canuel, R., and Zhong, S., 1989, The solubility of calcite and aragonite in sulfate-free seawater and the seeded growth kinetics and composition of the precipitates at $25^{\circ} \mathrm{C}$. Chemical Geology, v. 74, p. 309-320.

Nielsen, M.R., Sand, K.K., Rodriguez-Blanco, J.D., Bovet, N., Generosi, J., Dalby, K.N., and Stipp, S.L.S., 2016, Inhibition of Calcite Growth: Combined Effects of $\mathrm{Mg}^{2+}$ and $\mathrm{SO}_{4}{ }^{2-}$. Crystal Growth \& Design, v. 16, p. 6199-6207, doi:10.1021/acs.cgd.6b00536.

Ohmura, A., and Reeh, N., 1991, New precipitation and accumulation maps for Greenland. Journal of Glaciology, v. 37, no. 125.

Omelon, C.R., Pollard, W.H., and Marion, G.M., 2001, Seasonal formation of ikaite $\left(\mathrm{CaCO}_{3} \cdot 6 \mathrm{H}_{2} \mathrm{O}\right)$ in saline spring discharge at Expedition Fiord, Canadian High Arctic: Assessing conditional constraints for natural crystals growth. Geochimica et Cosmochimica Acta, v. 65, p. 1429-1437. 
Parkhurst, D.L., and Appelo, C.A.J., 2013, Description of input and examples for PHREEQC version 3-A computer program for speciation, batch-reaction, onedimensional transport, and inverse geochemical calculations: U.S. Geological Survey Techniques and Methods, book 6, chap. A43, 497 p., available only at https://pubs.usgs.gov/tm/06/a43/.

Pauly, H., 1963, “Ikaite”, A New Mineral from Greenland. Arctic v. 16, p. 263-264.

Pelouze, J., 1831, Sur la production artificielle du carbonate de chaux cristallise, et sur deux combinaisons de ce sel avec l'eau. Annales de Chimie et de Physique, ser. 2, v. 48, p. 301-307.

Rodriguez-Blanco, J.D., Shaw, S., Bots, P., Roncal-Herrero, T., and Benning, L.G., 2014, The role of $\mathrm{Mg}$ in the crystallization of monohydrocalcite. Geochimica et Cosmochimica Acta, v. 127, p. 204-220.

Rodriguez-Ruiz, I., Veesler, S., Gómez-Morales, J., Delgado-López, J.-M., Grauby, O., Hammadi, Z., Candoni, N. and García-Ruiz, J.M., 2014, Transient Calcium Carbonate Hexahydrate (Ikaite) Nucleated and Stabilized in Confined Nano- and Picovolumes. Crystal Growth, v. 14, p. 792-802.

Stockmann, G.J., Tollefsen, E., Balic-Zunic, T., Langhof, J. and Skogby, H., 2016, Synthetic ikaite precipitation simulating conditions in Ikka Fjord, SW Greenland. Abstract, 32nd Nordic Geological Winter Meeting, Helsinki, Finland.

Stumm, W., and Morgan, J.J., 1996, Aquatic Chemistry. Chemical Equilibria and Rates in Natural Waters. Third Edition. John Wiley \& Sons, Inc., New York, 1022 pp.

Toby, B.H., 2006, R factors in Rietveld analysis: How good is good enough? Powder diffraction, 21(01), 67-70. 
Trampe, E.C.L., Larsen, J.E.N., Glaring, M.A., Stougaard, P. and Kühl, M. 2016. In situ Dynamics of $\mathrm{O}_{2}, \mathrm{pH}$, Light, and Photosynthesis in Ikaite Tufa Columns (Ikka Fjord,Greenland) - A Unique Microbial Habitat. Frontiers in microbiology, 7. Upton B.G.J and Blundell D.J. 1978, The Gardar igneous province: Evidence for Proterozoic continental rifting. Petrology and Geochemistry of Continental Rifts, 163172. D. Reidel Publishing Company, Dordrecht, Holland. 


\section{FIGURES}
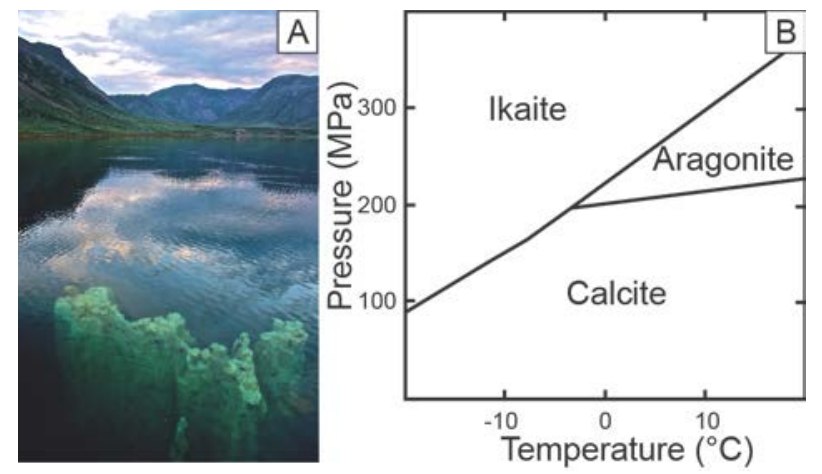

Figure 1. 1A) Ikaite column appearing at the surface of the water in Ikka Fjord. Photo: Richard Martin / www.coldzymes.dk 1B) The stability fields of ikaite, calcite and aragonite in the system CaCO3 - H2O. Modified from Marland (1975).
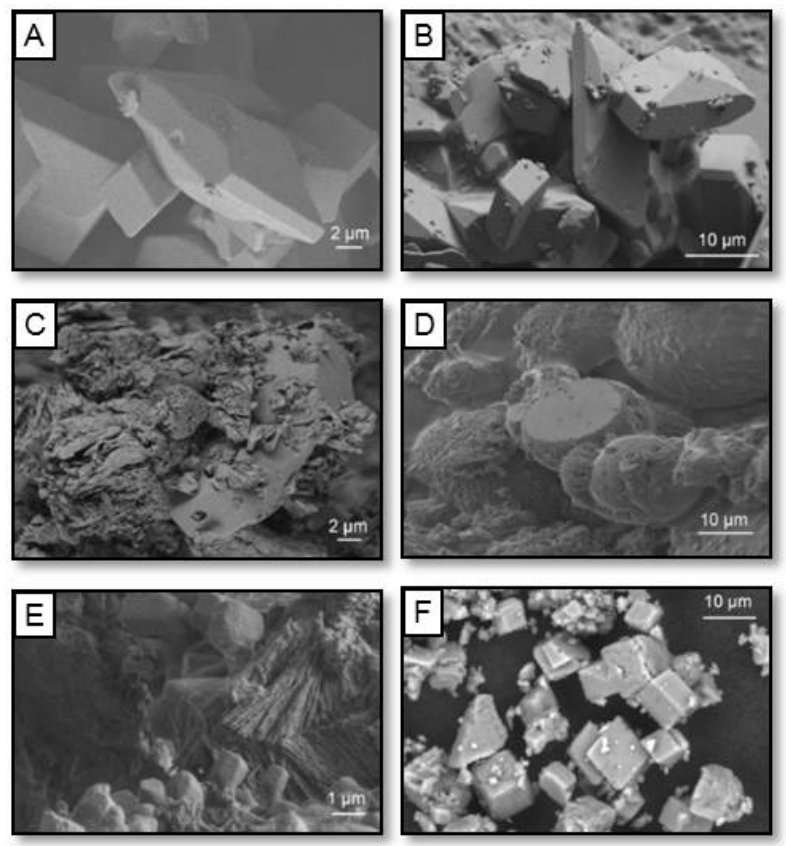

Figure 3. SEM images of experiments. 3A) Ikaite crystals from exp. 12b. 3B) Ikaite crystals from exp. 17. 3C) Calcite and/or ikaite from exp. 6b. 3D) Aragonite and/or calcite with spherulite morphology from exp. 35. 3E) Calcite with smooth rhomb shape from exp. 24. 3F) Calcite crystals from exp. 14.

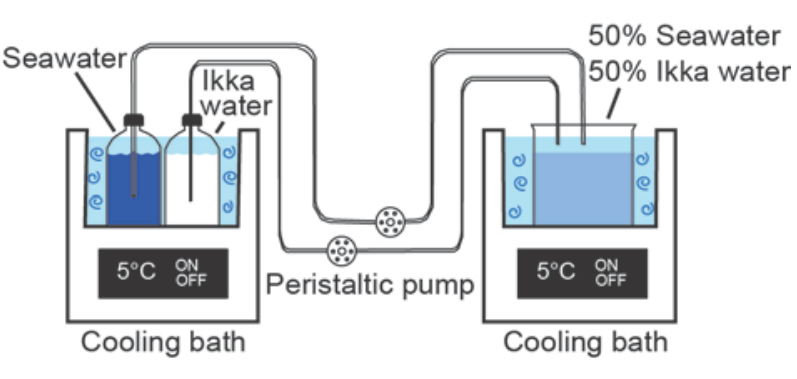

Figure 2. Experimental set-up. To the left the outlet solutions in the first cooling bath. Solutions are pumped in to a beaker in the second cooling bath.

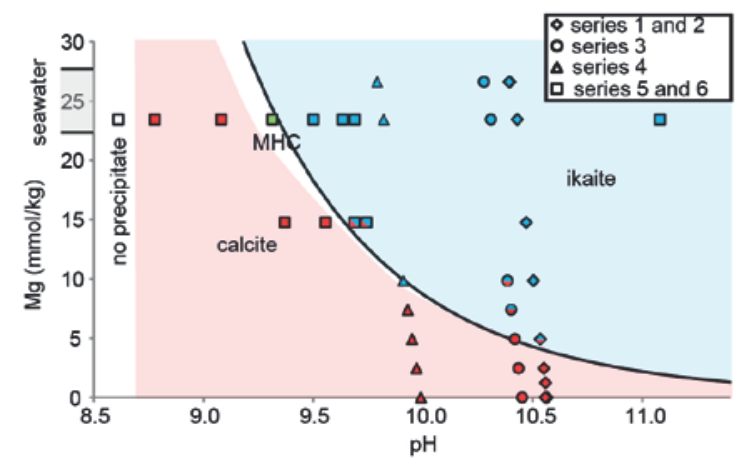

Figure 4. Kinetic stability diagram for ikaite and calcite precipitation as a function of $\mathrm{pH}$ and $\mathrm{Mg}$ concentration in solution at $5^{0} \mathrm{C}$. The blue symbols represent ikaite precipitations, the red symbols calcite precipitation and the green symbol monohydrocalcite (MHC). 


\section{TABLES}

TABLE 1. CHEMICAL ANALYSES OF SPRING WATER AND SEAWATER

\begin{tabular}{|c|c|c|c|}
\hline Component & Ikka waters* & $\begin{array}{c}\text { Andøya seawater } \\
\text { N 69¹6.981' E } 15^{\circ} 52.462^{\prime}\end{array}$ & "Synthetic seawater \\
\hline $\begin{array}{l}\text { conductivity } \\
(\mathrm{mS} / \mathrm{cm})\end{array}$ & $12.1-14.8$ & 50.5 & N.D. \\
\hline salinity (\%o) & $7.6-9.7$ & 33.1 & N.D. \\
\hline $\mathrm{pH}$ & $10.16-10.5$ & 8.07 & 7.78 \\
\hline temp $\left({ }^{\circ} \mathrm{C}\right)$ & $3.1-4.1$ & 5.0 & 5.0 \\
\hline Alkalinity $\mathrm{mmol} / \mathrm{L}$ & $114-179$ & $2.1378 \pm 0.002$ & N.D. \\
\hline $\mathrm{Na}^{+} \mathrm{mmol} / \mathrm{L}$ & $170-252$ & $432.15 \pm 1.18$ & $467.98 \pm 3.38$ \\
\hline $\mathrm{K}^{+} \mathrm{mmol} / \mathrm{L}$ & $1.7-2.3$ & $9.60 \pm 1.06$ & $10.19 \pm 0.13$ \\
\hline $\mathrm{Ca}^{2+} \mathrm{mmol} / \mathrm{L}$ & $0.09-0.24$ & $8.83 \pm 0.22$ & $10.18 \pm 0.18$ \\
\hline $\mathrm{Mg}^{2+} \mathrm{mmol} / \mathrm{L}$ & $0-2.71$ & $45.60 \pm 0.50$ & $53.22 \pm 0.05$ \\
\hline $\mathrm{Sr}^{2+} \mathrm{mmol} / \mathrm{L}$ & $0.005-0.007$ & $0.08 \pm 0.49$ & N.D. \\
\hline $\mathrm{Cl}^{-} \mathrm{mmol} / \mathrm{L}$ & $21.2-59$ & $533.59 \pm 2.37$ & $546.14 \pm 1.45$ \\
\hline $\mathrm{SO}_{4}{ }^{2-} \mathrm{mmol} / \mathrm{L}$ & $2.78-4.04$ & $27.31 \pm 0.50$ & $28.23 \pm 0.07$ \\
\hline $\mathrm{Br}^{-} \mathrm{mmol} / \mathrm{L}$ & $0.38-0.43$ & N.D. & N.D. \\
\hline $\mathrm{PO}_{4}{ }^{3-} \mu \mathrm{mol} / \mathrm{L}$ & $93-260$ & $<0.016$ & $<0.1$ \\
\hline Total C mmol/L & $67-96$ & $2.10 \pm 0.04$ & $2.38 \pm 0.12$ \\
\hline
\end{tabular}


TABLE 2. SUMMARY OF IKAITE EXPERIMENTS AT $5^{\circ} \mathrm{C}$

\begin{tabular}{|c|c|c|c|c|c|c|}
\hline \multirow[t]{2}{*}{ Exp. No. } & \multirow[t]{2}{*}{ Seawater type } & \multirow{2}{*}{$\begin{array}{l}\text { Ikka water } \\
\mathrm{Na}_{2} \mathrm{CO}_{3} \text { : } \\
\mathrm{NaHCO}_{3}\end{array}$} & \multicolumn{2}{|c|}{ Solution } & \multirow{2}{*}{$\begin{array}{l}\text { Precipi- } \\
\text { tate }(g)^{\#}\end{array}$} & \multirow[t]{2}{*}{ XRD analyses } \\
\hline & & & $\mathrm{pH}^{*}$ & $\mathrm{Mg}^{\dagger}$ & & \\
\hline \multicolumn{7}{|l|}{ 1st Series } \\
\hline 1 & $A$ & $4: 1$ & 10.43 & 22.80 & 0.1347 & $100 \% \mathrm{ik}$ \\
\hline 2 & s & $4: 1$ & 10.40 & 26.61 & 0.1756 & $100 \% \mathrm{ik}$ \\
\hline 3 & $\mathrm{~S}\left(-\mathrm{SO}_{4}\right)$ & $4: 1$ & 10.39 & 26.61 & 0.1282 & $100 \% \mathrm{ik}$ \\
\hline $4 a$ & $\mathrm{~s}(-\mathrm{Mg})$ & $4: 1$ & 10.57 & 0.00 & 0.0511 & $100 \% \mathrm{cal}$ \\
\hline \multicolumn{7}{|c|}{ 2nd Series } \\
\hline $6 a$ & $\mathrm{~s}(2 \mathrm{~g} \mathrm{Mg})$ & $4: 1$ & 10.53 & 4.92 & 0.1070 & $62 \%$ ik $22 \%$ cal $16 \%$ arg \\
\hline 7 & s (3g Mg) & $4: 1$ & 10.52 & 7.38 & 0.0965 & $63 \%$ ik $37 \%$ cal \\
\hline 8 & $\mathrm{~s}(4 \mathrm{~g} \mathrm{Mg})$ & $4: 1$ & 10.50 & 9.84 & 0.1148 & $100 \% \mathrm{ik}$ \\
\hline 11 & s (1g Mg) & $4: 1$ & 10.55 & 2.46 & 0.0506 & $91 \%$ cal $9 \%$ arg \\
\hline \multicolumn{7}{|l|}{ 5th Series } \\
\hline 26 & $A$ & 1:15 & 8.62 & 22.80 & 0.0000 & n.p. \\
\hline 28 & A & $1: 5$ & 9.09 & 22.80 & 0.0236 & $79 \%$ cal $21 \%$ arg \\
\hline 29 & $A$ & $1: 3$ & 9.32 & 22.80 & 0.0525 & $43 \%$ mhc $32 \%$ cal $25 \%$ ik \\
\hline 30 & A & $1: 2$ & 9.51 & 22.80 & 0.0272 & $100 \% \mathrm{ik}$ \\
\hline \multicolumn{7}{|l|}{ 6th Series } \\
\hline 35 & $\mathrm{~s}(6 \mathrm{~g} \mathrm{Mg})$ & $1: 2$ & 9.56 & 14.76 & 0.0609 & $80 \% \arg 20 \%$ cal \\
\hline 36 & $\mathrm{~s}(6 \mathrm{~g} \mathrm{Mg})$ & $2: 3$ & 9.69 & 14.76 & 0.0852 & $61 \%$ cal $39 \%$ ik \\
\hline \multicolumn{7}{|c|}{$\begin{array}{l}\text { Note: Temperature experiments } 5^{\circ} \mathrm{C} \text {. A- Andøya; s-synthetic; ik-ikaite; cal-calcite; vat-vaterite; } \\
\text { arg-aragonite; nq-nesquehonite; mhc-monohydrocalcite; n.p.-no precipitate }\end{array}$} \\
\hline \multicolumn{7}{|c|}{ * pH was calculated with PhreeqC. } \\
\hline \multirow{2}{*}{\multicolumn{7}{|c|}{$\begin{array}{l}{ }^{\dagger} \text { Mg in } \mathrm{mmol} / \mathrm{kg} \text {. With Andøya seav } \\
{ }^{*} \text { Minimum amount of precipitate. }\end{array}$}} \\
\hline & & & & & & \\
\hline \multicolumn{7}{|c|}{$\begin{array}{l}\text { Weighted profile R-factor (Rwp) was between } 8 \text { - 14\% except samples } 29 \text { Rwp }=16 \% .32 \\
\text { Rwp }=37 \% \text { and } 34 \text { Rwp = 20\%. R-factors values (Toby 2006). }\end{array}$} \\
\hline
\end{tabular}




\section{APPENDIX}

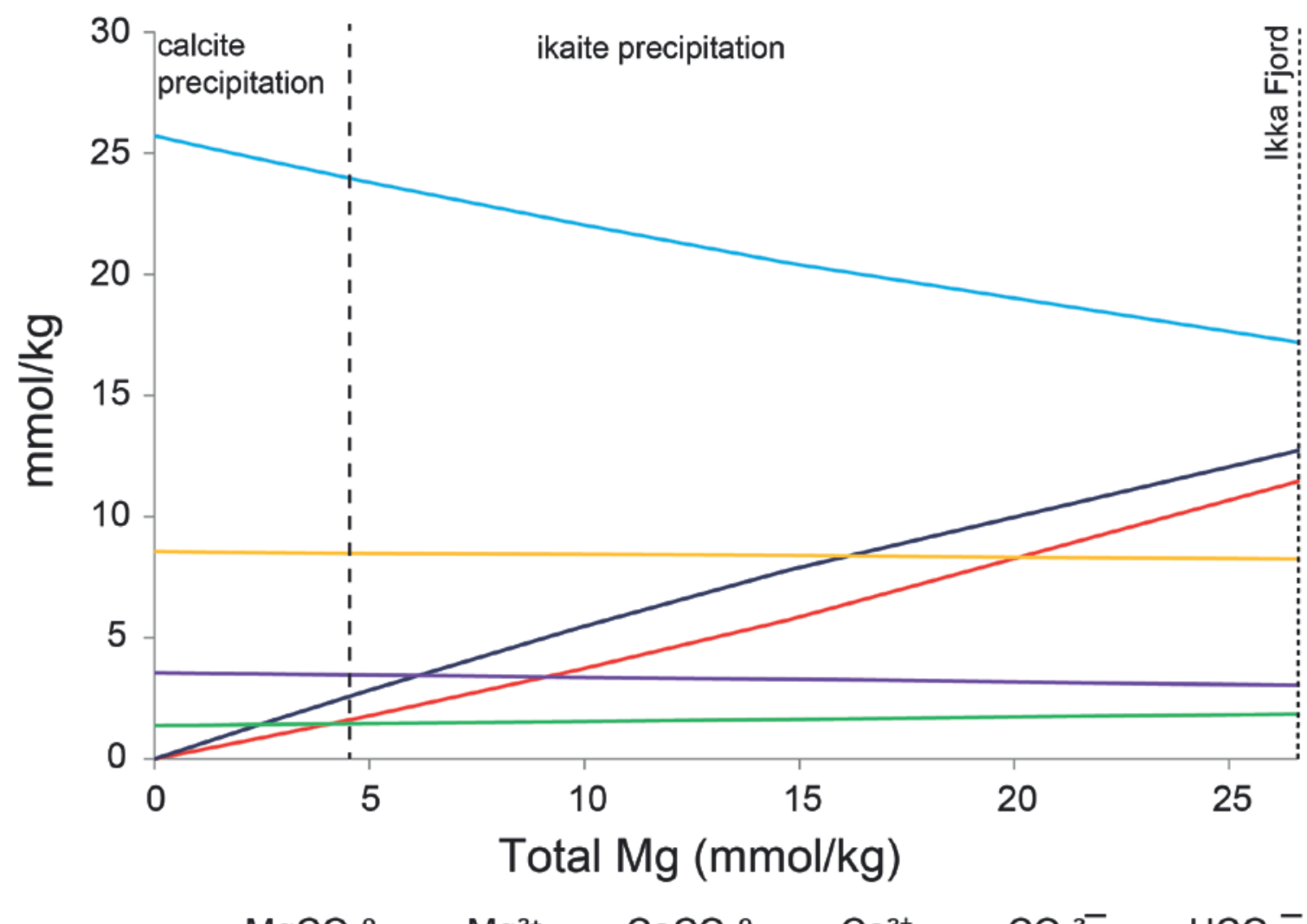

Figure A1. Ion speciation calculated with PhreeqC for the experiments in series 1 and 2 as a function of $\mathrm{Mg}$ concentration in solution. The dashed lines show the corresponding zones from the experiments as a function of $\mathrm{Mg}$ concentration in solution. 
TABLE A1. SUMMARY OF IKAITE EXPERIMENTS

\begin{tabular}{|c|c|c|c|c|c|c|}
\hline \multirow[t]{2}{*}{ Exp. No. } & \multirow{2}{*}{$\begin{array}{l}\text { Seawater } \\
\text { type }\end{array}$} & \multirow{2}{*}{$\begin{array}{c}\text { lkka } \\
\text { water } \\
\mathrm{Na}_{2} \mathrm{CO}_{3}: \\
\mathrm{NaHCO}_{3}\end{array}$} & \multicolumn{2}{|c|}{ Solution } & \multirow{2}{*}{$\begin{array}{l}\text { Precipi- } \\
\text { tate }(\mathrm{g})^{\#}\end{array}$} & \multirow[t]{2}{*}{ XRD analyses } \\
\hline & & & $\mathrm{pH}^{*}$ & $\mathrm{Mg}^{\dagger}$ & & \\
\hline \multicolumn{7}{|l|}{ 1st Series } \\
\hline 1 & $A$ & $4: 1$ & 10.43 & 22.80 & 0.1347 & $100 \% \mathrm{ik}$ \\
\hline 2 & $\mathrm{~s}$ & $4: 1$ & 10.40 & 26.61 & 0.1756 & $100 \% \mathrm{ik}$ \\
\hline 3 & $\mathrm{~S}\left(-\mathrm{SO}_{4}\right)$ & $4: 1$ & 10.39 & 26.61 & 0.1282 & $100 \% \mathrm{ik}$ \\
\hline $4 a$ & s (-Mg) & $4: 1$ & 10.57 & 0.00 & 0.0511 & $100 \% \mathrm{cal}$ \\
\hline $4 b$ & s (-Mg) & $4: 1$ & 10.57 & 0.00 & 0.0371 & $94 \%$ cal $6 \%$ vat \\
\hline 5 & $\mathrm{~s}(-\mathrm{Mg}) \mathrm{NaCl}$ & $4: 1$ & 10.56 & 0.00 & 0.0432 & $100 \% \mathrm{cal}$ \\
\hline \multicolumn{7}{|c|}{ 2nd Series } \\
\hline $6 a$ & $\mathrm{~s}(2 \mathrm{~g} \mathrm{Mg})$ & $4: 1$ & 10.53 & 4.92 & 0.1070 & $62 \%$ ik $22 \%$ cal $16 \%$ arg \\
\hline $6 b$ & $\mathrm{~s}(2 \mathrm{~g} \mathrm{Mg})$ & $4: 1$ & 10.53 & 4.92 & 0.0919 & $85 \%$ cal $15 \%$ ik \\
\hline 7 & $\mathrm{~s}(3 \mathrm{~g} \mathrm{Mg})$ & $4: 1$ & 10.52 & 7.38 & 0.0965 & $63 \%$ ik 37\% cal \\
\hline 8 & $\mathrm{~s}(4 \mathrm{~g} \mathrm{Mg})$ & $4: 1$ & 10.50 & 9.84 & 0.1148 & $100 \% \mathrm{ik}$ \\
\hline 9 & $\mathrm{~s}(6 \mathrm{~g} \mathrm{Mg})$ & $4: 1$ & 10.47 & 14.76 & 0.1226 & $100 \% \mathrm{ik}$ \\
\hline 10 & $\mathrm{~s}(0.5 \mathrm{~g} \mathrm{Mg})$ & $4: 1$ & 10.56 & 1.23 & 0.0546 & $100 \% \mathrm{cal}$ \\
\hline 11 & $\mathrm{~s}(1 \mathrm{~g} \mathrm{Mg})$ & $4: 1$ & 10.55 & 2.46 & 0.0506 & $91 \%$ cal $9 \%$ arg \\
\hline \multicolumn{7}{|l|}{ 3rd Series } \\
\hline $12 a$ & $A$ & $3: 1$ & 10.31 & 22.80 & 0.1198 & $57 \%$ ik $43 \%$ cal \\
\hline $12 b$ & $A$ & $3: 1$ & 10.31 & 22.80 & 0.1330 & $100 \% \mathrm{ik}$ \\
\hline 13 & $\mathrm{~s}$ & $3: 1$ & 10.28 & 26.61 & 0.1125 & $98 \%$ ik $2 \%$ nq \\
\hline 14 & s (-Mg) & $3: 1$ & 10.45 & 0.00 & 0.0502 & $100 \% \mathrm{cal}$ \\
\hline 15 & $\mathrm{~s}(1 \mathrm{~g} \mathrm{Mg})$ & $3: 1$ & 10.44 & 2.46 & 0.0743 & $100 \% \mathrm{cal}$ \\
\hline 16 & $\mathrm{~s}(2 \mathrm{~g} \mathrm{Mg})$ & $3: 1$ & 10.42 & 4.92 & 0.1167 & $91 \%$ cal $9 \%$ mhc \\
\hline $17 a$ & $\mathrm{~s}(3 \mathrm{~g} \mathrm{Mg})$ & $3: 1$ & 10.40 & 7.38 & 0.1022 & $91 \%$ cal $6 \%$ ik \\
\hline $17 b$ & $\mathrm{~s}(3 \mathrm{~g} \mathrm{Mg})$ & $3: 1$ & 10.40 & 7.38 & 0.1348 & $98 \%$ ik $2 \%$ cal \\
\hline 18 & $\mathrm{~s}(4 \mathrm{~g} \mathrm{Mg})$ & $3: 1$ & 10.39 & 9.84 & 0.0961 & $52 \%$ cal $48 \%$ ik \\
\hline \multicolumn{7}{|c|}{ 4th Series } \\
\hline $19 a$ & $A$ & $1: 1$ & 9.83 & 22.80 & 0.1082 & $66 \%$ ik $34 \%$ cal \\
\hline $19 b$ & $A$ & $1: 1$ & 9.83 & 22.80 & 0.1148 & $88 \%$ ik $12 \%$ cal \\
\hline 20 & $\mathrm{~s}$ & $1: 1$ & 9.79 & 26.61 & 0.0981 & $100 \% \mathrm{ik}$ \\
\hline 21 & s (-Mg) & $1: 1$ & 9.99 & 0.00 & 0.0439 & $100 \% \mathrm{cal}$ \\
\hline 22 & $\mathrm{~s}(1 \mathrm{~g} \mathrm{Mg})$ & $1: 1$ & 9.97 & 2.46 & 0.0366 & $100 \% \mathrm{cal}$ \\
\hline 23 & $\mathrm{~s}(2 \mathrm{~g} \mathrm{Mg})$ & $1: 1$ & 9.95 & 4.92 & 0.0648 & $89 \%$ cal $11 \%$ arg \\
\hline 24 & $\mathrm{~s}(3 \mathrm{~g} \mathrm{Mg})$ & $1: 1$ & 9.93 & 7.38 & 0.0603 & $100 \% \mathrm{cal}$ \\
\hline 25 & $\mathrm{~s}(4 \mathrm{~g} \mathrm{Mg})$ & $1: 1$ & 9.91 & 9.84 & 0.1622 & $100 \% \mathrm{ik}$ \\
\hline \multicolumn{7}{|l|}{ 5th Series } \\
\hline 26 & $A$ & 1:15 & 8.62 & 22.80 & 0.0000 & no precipitate \\
\hline 27 & $A$ & 1:10 & 8.78 & 22.80 & 0.0057 & $69 \%$ arg $31 \%$ cal \\
\hline 28 & $A$ & $1: 5$ & 9.09 & 22.80 & 0.0236 & $79 \%$ cal $21 \%$ arg \\
\hline 29 & $A$ & $1: 3$ & 9.32 & 22.80 & 0.0525 & $43 \%$ mhc $32 \%$ cal $25 \%$ ik \\
\hline 30 & $A$ & $1: 2$ & 9.51 & 22.80 & 0.0272 & $100 \% \mathrm{ik}$ \\
\hline 31 & $A$ & $2: 3$ & 9.64 & 22.80 & 0.0742 & $100 \% \mathrm{ik}$ \\
\hline 32 & $A$ & $3: 4$ & 9.69 & 22.80 & 0.0988 & $100 \% \mathrm{ik}$ \\
\hline 33 & $A$ & $1: 0$ & 11.09 & 22.80 & 0.2733 & ik + amorphus phase \\
\hline \multicolumn{7}{|l|}{ 6th Series } \\
\hline 34 & $\mathrm{~s}(6 \mathrm{~g} \mathrm{Mg})$ & $1: 3$ & 9.37 & 14.76 & 0.0513 & $100 \% \mathrm{cal}$ \\
\hline
\end{tabular}




\begin{tabular}{lllllll}
35 & $\mathrm{~s}(6 \mathrm{~g} \mathrm{Mg})$ & $1: 2$ & 9.56 & 14.76 & 0.0609 & $80 \%$ arg 20\% cal \\
36 & $\mathrm{~s}(6 \mathrm{~g} \mathrm{Mg})$ & $2: 3$ & 9.69 & 14.76 & 0.0852 & $61 \%$ cal 39\% ik \\
37 & $\mathrm{~s}(6 \mathrm{~g} \mathrm{Mg})$ & $3: 4$ & 9.74 & 14.76 & 0.1154 & $50 \%$ ik 50\% cal \\
\hline
\end{tabular}

Note: Temperature experiments $5^{\circ} \mathrm{C}$. A- Andøya; s-synthetic; ik-ikaite; cal-calcite; vatvaterite; arg-aragonite; nq-nesquehonite; mhc-monohydrocalcite; n.p.-no precipitate

* $\mathrm{pH}$ was calculated with PhreeqC.

${ }^{\dagger} \mathrm{Mg}$ in $\mathrm{mmol} / \mathrm{kg}$. With Andøya seawater s.d. \pm 0.5 , with synthetic seawater s.d. \pm 0.02 .

\# Minimum amount of precipitate.

${ }^{\star *}$ Weighted profile R-factor (Rwp) was between 8 - 14\% except samples 29 Rwp = 16\%. 32 Rwp $=37 \%$ and 34 Rwp $=20 \%$. R-factors values (Toby 2006). 
TABLE A2. MODELLING OF THE EXPERIMENTS IN PHREEQC

\begin{tabular}{|c|c|c|c|c|c|c|c|c|c|c|c|c|c|}
\hline \multirow{2}{*}{$\begin{array}{l}\text { Exp. } \\
\text { number }\end{array}$} & \multirow[t]{2}{*}{$\overline{\mathrm{pH}}$} & \multirow{2}{*}{$\begin{array}{l}\text { Tempera- } \\
\text { ture }\left({ }^{\circ} \mathrm{C}\right)\end{array}$} & \multirow{2}{*}{$\begin{array}{c}\text { Ionic } \\
\text { strength } \\
(\mathrm{mol} / \mathrm{kg})\end{array}$} & \multirow{2}{*}{$\begin{array}{l}\text { Alkalinity } \\
\text { (meq/kg) }\end{array}$} & \multicolumn{8}{|c|}{ Saturation Index } & \multirow[b]{2}{*}{$\begin{array}{l}\text { PhreeqC } \\
\% \text { error }\end{array}$} \\
\hline & & & & & Aragonite & Calcite & Ikaite & $\begin{array}{c}\text { Hydro- } \\
\text { magnesite }\end{array}$ & Magnesite & $\begin{array}{l}\text { Mono- } \\
\text { hydro- } \\
\text { calcite }\end{array}$ & $\begin{array}{l}\text { Nesque- } \\
\text { honite }\end{array}$ & Vaterite & \\
\hline \multicolumn{14}{|c|}{ 1st Series } \\
\hline 1 & 10.43 & 5 & 0.36 & 91 & 2.54 & 2.69 & 1.36 & 6.64 & 2.88 & 1.89 & -0.32 & 2.06 & -3.04 \\
\hline 2 & 10.40 & 5 & 0.38 & 91 & 2.58 & 2.73 & 1.40 & 6.83 & 2.92 & 1.94 & -0.28 & 2.10 & 0.00 \\
\hline 3 & 10.39 & 5 & 0.35 & 91 & 2.60 & 2.75 & 1.42 & 6.95 & 2.95 & 1.95 & -0.25 & 2.12 & 0.00 \\
\hline 4 & 10.57 & 5 & 0.35 & 91 & 2.65 & 2.80 & 1.47 & N.A. & N.A. & 2.01 & N.A. & 2.17 & 0.00 \\
\hline 5 & 10.56 & 5 & 0.38 & 91 & 2.64 & 2.79 & 1.46 & N.A. & N.A. & 2.00 & N.A. & 2.16 & 0.00 \\
\hline \multicolumn{14}{|c|}{ 2nd Series } \\
\hline 6 & 10.53 & 5 & 0.35 & 91 & 2.64 & 2.79 & 1.46 & 3.67 & 2.26 & 1.99 & -0.93 & 2.16 & 0.00 \\
\hline 7 & 10.52 & 5 & 0.35 & 91 & 2.64 & 2.78 & 1.45 & 4.49 & 2.43 & 1.99 & -0.76 & 2.15 & 0.00 \\
\hline 8 & 10.50 & 5 & 0.36 & 91 & 2.63 & 2.78 & 1.45 & 5.06 & 2.55 & 1.98 & -0.65 & 2.15 & 0.00 \\
\hline 9 & 10.47 & 5 & 0.36 & 91 & 2.62 & 2.76 & 1.43 & 5.83 & 2.71 & 1.97 & -0.49 & 2.14 & 0.00 \\
\hline 10 & 10.56 & 5 & 0.35 & 91 & 2.65 & 2.80 & 1.47 & 0.74 & 1.67 & 2.00 & -1.52 & 2.17 & 0.00 \\
\hline 11 & 10.55 & 5 & 0.35 & 91 & 2.65 & 2.79 & 1.46 & 2.22 & 1.97 & 2.00 & -1.23 & 2.17 & 0.00 \\
\hline \multicolumn{14}{|c|}{ 3rd Series } \\
\hline 12 & 10.31 & 5 & 0.36 & 89 & 2.53 & 2.67 & 1.34 & 6.35 & 2.86 & 1.88 & -0.34 & 2.04 & -3.05 \\
\hline 13 & 10.28 & 5 & 0.37 & 89 & 2.57 & 2.72 & 1.39 & 6.53 & 2.90 & 1.92 & -0.29 & 2.09 & 0.00 \\
\hline 14 & 10.45 & 5 & 0.34 & 89 & 2.64 & 2.79 & 1.46 & N.A. & N.A. & 2.00 & N.A. & 2.16 & 0.00 \\
\hline 15 & 10.44 & 5 & 0.34 & 89 & 2.64 & 2.79 & 1.46 & 1.95 & 1.96 & 1.99 & -1.24 & 2.16 & 0.00 \\
\hline 16 & 10.42 & 5 & 0.35 & 89 & 2.63 & 2.78 & 1.45 & 3.40 & 2.25 & 1.98 & -0.95 & 2.15 & 0.00 \\
\hline 17 & 10.40 & 5 & 0.35 & 89 & 2.63 & 2.77 & 1.44 & 4.22 & 2.42 & 1.98 & -0.78 & 2.14 & 0.00 \\
\hline 18 & 10.39 & 5 & 0.35 & 89 & 2.62 & 2.77 & 1.44 & 4.79 & 2.53 & 1.97 & -0.66 & 2.14 & 0.00 \\
\hline \multicolumn{14}{|c|}{ 4th Series } \\
\hline 19 & 9.83 & 5 & 0.35 & 76 & 2.43 & 2.58 & 1.25 & 4.95 & 2.73 & 1.78 & -0.46 & 1.95 & -3.11 \\
\hline 20 & 9.79 & 5 & 0.37 & 76 & 2.47 & 2.61 & 1.28 & 5.11 & 2.77 & 1.82 & -0.42 & 1.98 & 0.00 \\
\hline
\end{tabular}




\begin{tabular}{|c|c|c|c|c|c|c|c|c|c|c|c|c|c|}
\hline 21 & 9.99 & 5 & 0.32 & 76 & 2.58 & 2.72 & 1.39 & N.A. & N.A. & 1.93 & N.A. & 2.09 & 0.00 \\
\hline 22 & 9.97 & 5 & 0.33 & 76 & 2.57 & 2.71 & 1.38 & 0.73 & 1.86 & 1.92 & -1.33 & 2.09 & 0.00 \\
\hline 23 & 9.95 & 5 & 0.33 & 76 & 2.56 & 2.70 & 1.37 & 2.15 & 2.15 & 1.91 & -1.04 & 2.08 & 0.00 \\
\hline 24 & 9.93 & 5 & 0.33 & 76 & 2.55 & 2.69 & 1.36 & 2.95 & 2.31 & 1.90 & -0.88 & 2.07 & 0.00 \\
\hline 25 & 9.91 & 5 & 0.34 & 76 & 2.54 & 2.68 & 1.35 & 3.49 & 2.43 & 1.89 & -0.77 & 2.06 & 0.00 \\
\hline \multicolumn{14}{|c|}{ 5th Series } \\
\hline 26 & 8.62 & 5 & 0.34 & 54 & 1.71 & 1.86 & 0.53 & -0.50 & 1.94 & 1.06 & -1.26 & 1.23 & -3.19 \\
\hline 27 & 8.78 & 5 & 0.34 & 56 & 1.85 & 1.99 & 0.66 & 0.40 & 2.08 & 1.20 & -1.11 & 1.36 & -3.19 \\
\hline 28 & 9.09 & 5 & 0.34 & 59 & 2.07 & 2.22 & 0.89 & 1.95 & 2.32 & 1.43 & -0.87 & 1.59 & -3.18 \\
\hline 29 & 9.32 & 5 & 0.34 & 64 & 2.22 & 2.36 & 1.03 & 3.02 & 2.48 & 1.57 & -0.71 & 1.73 & -3.16 \\
\hline 30 & 9.51 & 5 & 0.34 & 68 & 2.31 & 2.46 & 1.13 & 3.80 & 2.59 & 1.66 & -0.60 & 1.83 & -3.15 \\
\hline 31 & 9.64 & 5 & 0.35 & 71 & 2.37 & 2.51 & 1.18 & 4.31 & 2.66 & 1.72 & -0.54 & 1.88 & -3.14 \\
\hline 32 & 9.69 & 5 & 0.35 & 72 & 2.39 & 2.53 & 1.20 & 4.50 & 2.68 & 1.74 & -0.51 & 1.90 & -3.13 \\
\hline 33 & 11.09 & 5 & 0.38 & 101 & 2.58 & 2.72 & 1.39 & 7.93 & 2.89 & 1.93 & -0.31 & 2.09 & -2.97 \\
\hline \multicolumn{14}{|c|}{ 6th Series } \\
\hline 34 & 9.37 & 5 & 0.33 & 64 & 2.32 & 2.46 & 1.13 & 2.34 & 2.34 & 1.67 & -0.86 & 1.83 & 0.00 \\
\hline 35 & 9.56 & 5 & 0.34 & 68 & 2.41 & 2.55 & 1.22 & 3.10 & 2.44 & 1.76 & -0.75 & 1.92 & 0.00 \\
\hline 36 & 9.69 & 5 & 0.34 & 71 & 2.46 & 2.61 & 1.28 & 3.59 & 2.51 & 1.81 & -0.69 & 1.98 & 0.00 \\
\hline 37 & 9.74 & 5 & 0.34 & 73 & 2.48 & 2.62 & 1.29 & 3.78 & 2.53 & 1.83 & -0.67 & 1.99 & 0.00 \\
\hline
\end{tabular}


TABLE A3. MODELLING OF THE EXPERIMENTS IN PHREEQC

\begin{tabular}{|c|c|c|c|c|c|c|c|c|c|c|c|c|c|c|c|c|}
\hline $\begin{array}{l}\text { Exp. } \\
\text { number }\end{array}$ & " total $\mathrm{Mg}$ & $\mathrm{Mg}^{2^{+}}$ & $\mathrm{MgCO}_{3}{ }^{0}$ & total S & $\mathrm{SO}_{4}{ }^{2-}$ & $\mathrm{NaSO}_{4}{ }^{-}$ & $\mathrm{CaSO}_{4}{ }^{0}$ & 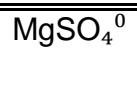 & total $\mathrm{Ca}$ & $\mathrm{CaCO}_{3}{ }^{0}$ & $\mathrm{Ca}^{2+}$ & " total C & $\mathrm{CO}_{3}{ }^{2-}$ & $\mathrm{HCO}_{3}{ }^{-}$ & $\mathrm{NaCO}_{3}{ }^{-}$ & $\mathrm{NaHCO}_{3}{ }^{0}$ \\
\hline \multicolumn{17}{|c|}{ 1st Series } \\
\hline 1 & 22.80 & 9.35 & 11.45 & 13.66 & 8.80 & 3.68 & 0.10 & 1.00 & 4.42 & 2.74 & 1.50 & 50.99 & 18.56 & 8.24 & 7.18 & 2.47 \\
\hline 2 & 26.61 & 11.45 & 12.72 & 14.12 & 8.85 & 3.86 & 0.12 & 1.21 & 5.09 & 3.04 & 1.84 & 51.19 & 17.19 & 8.25 & 6.96 & 2.60 \\
\hline 3 & 26.61 & 11.84 & 13.47 & 0.00 & 0.00 & 0.00 & 0.00 & 0.00 & 5.09 & 3.15 & 1.85 & 51.19 & 16.81 & 8.36 & 6.48 & 2.47 \\
\hline 4 & 0.00 & 0.00 & 0.00 & 14.12 & 9.63 & 4.30 & 0.10 & 0.00 & 5.09 & 3.56 & 1.37 & 51.19 & 25.72 & 8.55 & 10.62 & 2.71 \\
\hline 5 & 0.00 & 0.00 & 0.00 & 14.12 & 9.44 & 4.50 & 0.10 & 0.00 & 5.09 & 3.48 & 1.44 & 51.19 & 25.25 & 8.37 & 11.16 & 2.89 \\
\hline \multicolumn{17}{|c|}{ 2nd Series } \\
\hline 6 & 4.92 & 1.75 & 2.80 & 14.12 & 9.49 & 4.23 & 0.11 & 0.21 & 5.09 & 3.47 & 1.45 & 51.19 & 23.82 & 8.49 & 9.82 & 2.69 \\
\hline 7 & 7.38 & 2.68 & 4.12 & 22.80 & 9.42 & 4.19 & 0.11 & 0.31 & 5.09 & 3.42 & 1.49 & 51.19 & 22.93 & 8.47 & 9.44 & 2.68 \\
\hline 8 & 9.84 & 3.66 & 5.39 & 26.61 & 9.35 & 4.15 & 0.11 & 0.42 & 5.09 & 3.37 & 1.53 & 51.19 & 22.08 & 8.44 & 9.07 & 2.67 \\
\hline 9 & 14.76 & 5.74 & 7.78 & 26.61 & 9.21 & 4.07 & 0.12 & 0.65 & 5.09 & 3.28 & 1.62 & 51.19 & 20.47 & 8.39 & 8.38 & 2.65 \\
\hline 10 & 1.23 & 0.42 & 0.72 & 0.00 & 9.59 & 4.29 & 0.11 & 0.05 & 5.09 & 3.53 & 1.39 & 51.19 & 25.23 & 8.54 & 10.41 & 2.70 \\
\hline 11 & 2.46 & 0.85 & 1.42 & 0.00 & 9.56 & 4.27 & 0.11 & 0.10 & 5.09 & 3.51 & 1.41 & 51.19 & 24.75 & 8.52 & 10.21 & 2.70 \\
\hline \multicolumn{17}{|c|}{ 3rd Series } \\
\hline 12 & 22.80 & 10.04 & 11.20 & 13.66 & 8.79 & 3.65 & 0.11 & 1.04 & 4.42 & 2.66 & 1.57 & 50.99 & 17.18 & 10.09 & 6.61 & 3.00 \\
\hline 13 & 26.61 & 11.82 & 12.19 & 14.12 & 8.83 & 3.83 & 0.13 & 1.25 & 5.09 & 2.94 & 1.92 & 51.19 & 15.91 & 10.06 & 6.40 & 3.15 \\
\hline 14 & 0.00 & 0.00 & 0.00 & 14.12 & 9.63 & 4.29 & 0.11 & 0.00 & 5.09 & 3.48 & 1.42 & 51.19 & 24.04 & 10.44 & 9.89 & 3.28 \\
\hline 15 & 2.46 & 0.88 & 1.38 & 14.12 & 9.56 & 4.26 & 0.11 & 0.11 & 5.09 & 3.44 & 1.47 & 51.19 & 23.11 & 10.40 & 9.50 & 3.27 \\
\hline 16 & 4.92 & 1.81 & 2.71 & 14.12 & 9.49 & 4.22 & 0.11 & 0.21 & 5.09 & 3.39 & 1.51 & 51.19 & 22.21 & 10.37 & 9.12 & 3.26 \\
\hline 17 & 7.38 & 2.77 & 3.99 & 14.12 & 9.42 & 4.18 & 0.12 & 0.33 & 5.09 & 3.34 & 1.55 & 51.19 & 21.35 & 10.34 & 8.75 & 3.25 \\
\hline 18 & 9.84 & 3.78 & 5.21 & 14.12 & 9.35 & 4.14 & 0.12 & 0.44 & 5.09 & 3.29 & 1.60 & 51.19 & 20.53 & 10.30 & 8.40 & 3.24 \\
\hline \multicolumn{17}{|c|}{ 4th Series } \\
\hline 19 & 22.80 & 11.96 & 8.39 & 13.66 & 8.70 & 3.50 & 0.14 & 1.25 & 4.42 & 2.12 & 1.98 & 50.99 & 10.64 & 19.39 & 3.96 & 5.55 \\
\hline 20 & 26.61 & 13.99 & 9.03 & 14.12 & 8.73 & 3.67 & 0.16 & 1.48 & 5.09 & 2.32 & 2.41 & 51.19 & 9.82 & 19.18 & 3.83 & 5.79 \\
\hline 21 & 0.00 & 0.00 & 0.00 & 14.12 & 9.66 & 4.23 & 0.15 & 0.00 & 5.09 & 2.98 & 1.81 & 51.19 & 15.67 & 19.99 & 6.32 & 6.10 \\
\hline 22 & 2.46 & 1.06 & 1.11 & 14.12 & 9.57 & 4.18 & 0.15 & 0.13 & 5.09 & 2.92 & 1.86 & 51.19 & 14.94 & 19.91 & 6.01 & 6.08 \\
\hline
\end{tabular}




\begin{tabular}{|c|c|c|c|c|c|c|c|c|c|c|c|c|c|c|c|c|}
\hline 23 & 4.92 & 2.18 & 2.16 & 14.12 & 9.49 & 4.13 & 0.15 & 0.27 & 5.09 & 2.85 & 1.92 & 51.19 & 14.25 & 19.84 & 5.72 & 6.05 \\
\hline 24 & 7.38 & 3.35 & 3.14 & 14.12 & 9.40 & 4.08 & 0.15 & 0.40 & 5.09 & 2.79 & 1.98 & 51.19 & 13.60 & 19.77 & 5.45 & 6.02 \\
\hline 25 & 9.84 & 4.56 & 4.07 & 14.12 & 9.31 & 4.03 & 0.15 & 0.54 & 5.09 & 2.73 & 2.04 & 51.19 & 13.00 & 19.70 & 5.19 & 6.00 \\
\hline \multicolumn{17}{|c|}{ 5th Series } \\
\hline 26 & 22.80 & 16.72 & 1.33 & 13.66 & 8.44 & 3.18 & 0.23 & 1.74 & 4.42 & 0.40 & 3.32 & 50.99 & 1.19 & 35.37 & 0.41 & 9.37 \\
\hline 27 & 22.80 & 16.37 & 1.86 & 13.66 & 8.46 & 3.20 & 0.22 & 1.71 & 4.42 & 0.56 & 3.20 & 50.99 & 1.69 & 34.41 & 0.59 & 9.16 \\
\hline 28 & 22.80 & 15.44 & 3.25 & 13.66 & 8.51 & 3.26 & 0.20 & 1.61 & 4.42 & 0.93 & 2.91 & 50.99 & 3.14 & 31.71 & 1.11 & 8.57 \\
\hline 29 & 22.80 & 14.47 & 4.69 & 13.66 & 8.56 & 3.33 & 0.18 & 1.51 & 4.42 & 1.30 & 2.62 & 50.99 & 4.86 & 28.67 & 1.74 & 7.86 \\
\hline 30 & 22.80 & 13.56 & 6.03 & 13.66 & 8.61 & 3.39 & 0.16 & 1.42 & 4.42 & 1.62 & 2.38 & 50.99 & 6.69 & 25.59 & 2.43 & 7.12 \\
\hline 31 & 22.80 & 12.89 & 7.03 & 13.66 & 8.65 & 3.44 & 0.15 & 1.35 & 4.42 & 1.84 & 2.21 & 50.99 & 8.22 & 23.11 & 3.02 & 6.50 \\
\hline 32 & 22.80 & 12.61 & 7.43 & 13.66 & 8.66 & 3.46 & 0.15 & 1.32 & 4.42 & 1.93 & 2.14 & 50.99 & 8.90 & 22.05 & 3.28 & 6.23 \\
\hline 33 & 22.80 & 8.03 & 12.09 & 13.66 & 8.90 & 3.78 & 0.09 & 0.82 & 4.42 & 2.98 & 1.31 & 50.99 & 23.70 & 2.29 & 9.35 & 0.71 \\
\hline \multicolumn{17}{|c|}{$\underline{6 \text { th Series }}$} \\
\hline 34 & 14.76 & 8.78 & 3.31 & 14.12 & 9.04 & 3.77 & 0.21 & 1.02 & 5.09 & 1.64 & 2.90 & 51.19 & 5.46 & 28.87 & 2.10 & 8.45 \\
\hline 35 & 14.76 & 8.17 & 4.22 & 14.12 & 9.08 & 3.83 & 0.19 & 0.95 & 5.09 & 2.01 & 2.61 & 51.19 & 7.51 & 25.78 & 2.92 & 7.64 \\
\hline 36 & 14.76 & 7.73 & 4.87 & 14.12 & 9.10 & 3.87 & 0.18 & 0.89 & 5.09 & 2.27 & 2.41 & 51.19 & 9.23 & 23.29 & 3.62 & 6.97 \\
\hline 37 & 14.76 & 7.55 & 5.14 & 14.12 & 9.12 & 3.89 & 0.17 & 0.87 & 5.09 & 2.37 & 2.33 & 51.19 & 9.98 & 22.22 & 3.93 & 6.68 \\
\hline
\end{tabular}

